\title{
Seasonal changes in Fe species and soluble Fe concentration in the atmosphere in the Northwest Pacific region based on the analysis of aerosols collected in Tsukuba, Japan
}

\author{
Y. Takahashi ${ }^{1,2,3, *}$, T. Furukawa ${ }^{1}$, Y. Kanai ${ }^{4}$, M. Uematsu' ${ }^{2}$, G. Zheng ${ }^{3}$, and M. A. Marcus ${ }^{5}$ \\ ${ }^{1}$ Department of Earth and Planetary Systems Science, Graduate School of Science, Hiroshima University, Higashi-Hiroshima, \\ Hiroshima 739-8526, Japan \\ ${ }^{2}$ Atmosphere and Ocean Research Institute, The University of Tokyo, 5-1-5 Kashiwanoha, Kashiwa, Chiba 277-8564, Japan \\ ${ }^{3}$ Key Laboratory of Petroleum Resources, Chinese Academy of Sciences, 382 Donggang Road, Lanzhou 730000, China \\ ${ }^{4}$ Geological Survey of Japan, National Institute of Advanced Industrial Science and Technology (AIST), 1-1-1 Higashi, \\ Tsukuba, Ibaraki 305-8567, Japan \\ ${ }^{5}$ Advanced Light Source, Lawrence Berkeley National Laboratory, Berkeley, CA 94720, USA \\ Correspondence to: Y. Takahashi (ytakaha@ hiroshima-u.ac.jp)
}

Received: 21 January 2013 - Published in Atmos. Chem. Phys. Discuss.: 20 March 2013

Revised: 26 June 2013 - Accepted: 28 June 2013 - Published: 9 August 2013

\begin{abstract}
Atmospheric iron (Fe) can be a significant source of nutrition for phytoplankton inhabiting remote oceans, which in turn has a large influence on the Earth's climate. The bioavailability of $\mathrm{Fe}$ in aerosols depends mainly on the fraction of soluble $\mathrm{Fe}\left(=\left[\mathrm{Fe}_{\mathrm{Sol}}\right] /\left[\mathrm{Fe}_{\text {Total }}\right]\right.$, where $\left[\mathrm{Fe}_{\mathrm{Sol}}\right]$ and $\left[\mathrm{Fe}_{\mathrm{Total}}\right]$ are the atmospheric concentrations of soluble and total $\mathrm{Fe}$, respectively). However, the numerous factors affecting the soluble Fe fraction have not been fully understood. In this study, the Fe species, chemical composition, and soluble Fe concentrations in aerosols collected in Tsukuba, Japan were investigated over a year (nine samples from December 2002 to October 2003) to identify the factors affecting the amount of soluble Fe supplied into the ocean. The soluble Fe concentration in aerosols is correlated with those of sulfate and oxalate originated from anthropogenic sources, suggesting that soluble $\mathrm{Fe}$ is mainly derived from anthropogenic sources. Moreover, the soluble Fe concentration is also correlated with the enrichment factors of vanadium and nickel emitted by fossil fuel combustion. These results suggest that the degree of Fe dissolution is influenced by the magnitude of anthropogenic activity, such as fossil fuel combustion.

$\mathrm{X}$-ray absorption fine structure (XAFS) spectroscopy was performed in order to identify the Fe species in aerosols. Fitting of XAFS spectra coupled with micro X-ray fluorescence analysis ( $\mu$-XRF) showed the main $\mathrm{Fe}$ species in aerosols
\end{abstract}

in Tsukuba to be illite, ferrihydrite, hornblende, and Fe(III) sulfate. Moreover, the soluble Fe fraction in each sample measured by leaching experiments is closely correlated with the $\mathrm{Fe}(\mathrm{III})$ sulfate fraction determined by the XAFS spectrum fitting, suggesting that $\mathrm{Fe}(\mathrm{III})$ sulfate is the main soluble $\mathrm{Fe}$ in the ocean. Another possible factor that can control the amount of soluble Fe supplied into the ocean is the total $\mathrm{Fe}(\mathrm{III})$ concentration in the atmosphere, which was high in spring due to the high mineral dust concentrations during spring in East Asia. However, this factor does not contribute to the amount of soluble Fe to a larger degree than the effect of Fe speciation, or more strictly speaking the presence of Fe(III) sulfate. Therefore, based on these results, the most significant factor influencing the amount of soluble $\mathrm{Fe}$ in the North Pacific region is the concentration of anthropogenic Fe species such as Fe(III) sulfate that can be emitted from megacities in Eastern Asia.

\section{Introduction}

Oceanic areas where phytoplankton growth is limited by iron $(\mathrm{Fe})$ concentration are called "high nutrient, low chlorophyll (HNLC)" regions (Martin and Fitzwater, 1988), which account for $20 \%$ to $30 \%$ of the world's oceans (Martin, 1990; 
Jickells et al., 2005; Boyd and Ellwood, 2010). The concentration of bioavailable $\mathrm{Fe}$ in the euphotic zone in the ocean can influence the photosynthesis of phytoplankton in the HNLC, which can consequently affect the carbon cycle on the Earth's surface. Moreover, the amount of Fe in remote oceans can increase the production of dimethyl sulfide and/or organic carbon from microorganisms in the ocean, which in turn affects the radiative forcing in the atmosphere (Bishop et al., 2002; Boyd et al., 2007). Thus, understanding the processes of Fe supply and dissolution Fe from the atmosphere into the ocean is essential in estimating the impact of $\mathrm{Fe}$ on the Earth's climate.

Previous studies have demonstrated that several sources of $\mathrm{Fe}$, such as (1) atmospheric particles (Duce et al., 1991), (2) the continental shelf (Lam and Bishop, 2008), (3) islands in the ocean (Martinez and Maamaatuaiahutapu, 2004), (4) volcanic dust (Langmann et al., 2010), and (5) shipboard aerosol sources (Ito et al., 2013) provide significant soluble Fe to phytoplankton inhabiting remote oceans. Among these $\mathrm{Fe}$ sources, $\mathrm{Fe}$ in aerosols can be an important fraction (Duce et al., 1991; Jickells and Spokes, 2001). Therefore, several previous studies have investigated the soluble Fe concentration in the atmosphere to understand the influence of airborne $\mathrm{Fe}$ on the Earth's surface environment (e.g. Baker and Jickells, 2006; Buck et al., 2010; Sedwick et al., 2007; AguilarIslas et al., 2010).

However, the factors controlling soluble $\mathrm{Fe}$ fractions in aerosols have not been understood fully because a number of factors are involved (Mahowald et al., 2005). Thus, the atmospheric concentrations of total $\mathrm{Fe}\left(\left[\mathrm{Fe}_{\text {Total }}\right]\right)$ and soluble $\mathrm{Fe}\left(\left[\mathrm{Fe}_{\mathrm{Sol}}\right]\right)$, both in $\mathrm{ng} \mathrm{m}^{-3}$ need to be distinguished from soluble Fe fractions $\left(f_{\mathrm{sol}}=\left[\mathrm{Fe}_{\mathrm{Sol}}\right] /\left[\mathrm{Fe}_{\text {Total }}\right]\right)$ in the aerosols. For example, the soluble $\mathrm{Fe}$ fraction is influenced by the source(s) (Sedwick et al., 2007; Aguilar-Islas et al., 2010; Paris et al., 2010), aerosol size (Baker and Jickells, 2006; Ooki et al., 2009), and mineralogy (Journet et al., 2008) of the aerosols, as well as heterogeneous reactions with acids in the atmosphere (Spokes and Jickells, 1996; Mackie et al., 2005; Shi et al., 2009).

The atmospheric concentration of soluble $\mathrm{Fe}\left(=\left[\mathrm{Fe}_{\mathrm{Sol}}\right]\right)$, which is important in understanding the amount of bioavailable $\mathrm{Fe}$ to the ocean, is the product of $\left[\mathrm{Fe}_{\mathrm{Total}}\right]$ and the soluble Fe fraction $\left(=f_{\text {sol }}\right):\left[\mathrm{Fe}_{\mathrm{Sol}}\right]=f_{\text {sol }} \times\left[\mathrm{Fe}_{\text {Total }}\right]$. Here, $\left[\mathrm{Fe}_{\text {Total }}\right]$ should also be important to consider [ $\left.\mathrm{Fe}_{\mathrm{Sol}}\right]$, which can be increased during spring in the North Pacific region due to the supply of mineral dust from China. On the other hand, some reports have suggested that $\mathrm{Fe}$ from anthropogenic sources is highly soluble, therefore can be a significant source of bioavailable Fe dissolved in the ocean (Sedwick et al., 2007; Luo et al., 2008; Schroth et al., 2009; Sholkovitz et al., 2009; Kumar and Sarin, 2010).

In this study, we used X-ray absorption fine structure (XAFS), which is a powerful analytical tool to identify chemical species of $\mathrm{Fe}$ and other elements in aerosols to speciate $\mathrm{Fe}$ in aerosols (Majestic et al., 2007; Schroth et al.,
2009; Takahashi et al., 2011; Oakes et al., 2012a, b; Furukawa and Takahashi, 2011). Identifying the $\mathrm{Fe}$ species in aerosols can improve understanding of the factors controlling $\left[\mathrm{Fe}_{S o l}\right] /\left[\mathrm{Fe}_{\text {Total }}\right]$, because this ratio is strongly related to the Fe species. XAFS consists of X-ray absorption near edge structure (XANES) and extended X-ray absorption fine structure (EXAFS) which can determine the chemical species of each element in aerosols. We also conducted leaching experiments with two leaching solutions to study the relationship between the $\left[\mathrm{Fe}_{\mathrm{Sol}}\right] /\left[\mathrm{Fe}_{\text {Total }}\right]$ ratio and $\mathrm{Fe}$ species. By combining atmospheric Fe concentration, XAFS analysis, and leaching experiments, we revealed important factors controlling the supply of soluble Fe into the ocean.

Aerosol samples used in this study were collected through one year (nine samples collected at different months from December 2002 to October 2003; Table 1) in Tsukuba, $60 \mathrm{~km}$ northeast from Tokyo, Japan, at $36.06^{\circ} \mathrm{N}, 140.14^{\circ} \mathrm{E}$. Although the sampling period does not cover the whole year round, the collection of the sample from December 2002 to October 2003 can give us an idea of variation of [ $\left.\mathrm{Fe}_{\mathrm{Sol}}\right]$ and $\left[\mathrm{Fe}_{\mathrm{Total}}\right]$ in the atmosphere. Tsukuba is a site suitable for characterizing aerosols that can be transported to the Northwest Pacific by westerlies. The various sources of aerosols in Tsukuba include (i) mineral dust from the continent, (ii) anthropogenic aerosols from megacities and industrial areas around Tokyo and from the continent, and (iii) marine aerosols from the Pacific Ocean. Considering these three sources vary depending on the season, determining the seasonal variations in the contribution of each factor to the $\mathrm{Fe}$ speciation in aerosols related to the $\left[\mathrm{Fe}_{\mathrm{Sol}}\right] /\left[\mathrm{Fe}_{\text {Total }}\right]$ is important.

\section{Materials and methods}

\subsection{Aerosol samples and characterization}

The total suspended particles (TSP) in the atmosphere were determined in this study using a high-volume air sampler (Sibata, HV-1000F, Tokyo, Japan) at Tsukuba (Latitude: $36.06^{\circ} \mathrm{N}$, Longtitude: $140.14^{\circ} \mathrm{E}$, Height: $44 \mathrm{~m}$ a.s.l.) from December 2002 to October 2003 as part of the Japan-China joint project, "Asian Dust Experiment on Climate Impact" (Kanai et al., 2003; Table 1). This method can collect dry deposition or total suspended particles (TSP) in the atmosphere, whereas wet deposition samples were not collected in this study. The flow rate of the air sampler during sampling was maintained at $1000 \mathrm{~L} \mathrm{~min}^{-1}$, and polyflon filters $(25 \mathrm{~cm} \times 20 \mathrm{~cm}$; Advantec, PF40) were used for collecting aerosols. The filters were weighed before and after sampling with a reading precision of $10 \mu \mathrm{g}$ after stabilizing the weight under constant humidity in a desiccator. The filters with aerosols were preserved in a desiccator to prevent the chemical change of $\mathrm{Fe}$ in the aqueous phase at aerosol surfaces. Three-dimensional air mass back trajectories were 
Table 1. Periods for the collection of the TSP samples used in this study.

\begin{tabular}{|c|c|c|c|c|c|}
\hline & Start & Stop & $\begin{array}{r}\text { TSP } \\
\text { concentration } \\
\left(\mathrm{mg} \mathrm{m}^{-3}\right)\end{array}$ & $\begin{array}{r}\text { Total precipitation } \\
\text { during the period } \\
(\mathrm{mm})^{\mathrm{a}}\end{array}$ & $\begin{array}{r}\text { Number of rain events } \\
\text { (total precipitation }>5 \mathrm{~mm} \text { ) } \\
\text { during the period }^{\mathrm{a}}\end{array}$ \\
\hline December & 17.12 .2002 & 08.01 .2003 & 29.25 & 50 & $2\left(3\right.$ days $\left.^{b}\right)$ \\
\hline February & 13.02 .2003 & 24.02 .2003 & 42.55 & 27 & 2 (2 days) \\
\hline March & 14.03 .2003 & 25.03 .2003 & 41.41 & 8.5 & 2 (3 days) \\
\hline May & 01.05 .2003 & 12.05 .2003 & 54.26 & 17.5 & 1 (1 day) \\
\hline June & 11.06.2003 & 20.06.2003 & 36.55 & 12.5 & 1 (2 days) \\
\hline July & 11.07.2003 & 22.07.2003 & 29.39 & 56.5 & 3 (4 days) \\
\hline August & 12.08.2003 & 21.08.2003 & 14.54 & 199 & 2 (3 days) \\
\hline September & 22.09.2003 & 30.09 .2003 & 20.84 & 19 & 1 (2 days) \\
\hline October & 10.10 .2003 & 21.10 .2003 & 28.17 & 77.5 & 1 (2 days) \\
\hline
\end{tabular}

${ }^{a}$ Data from website of Japan Meteorological Agency (http://www.jma.go.jp/jma/index.html), ${ }^{b}$ Number of days covered by the rain events during the period.

calculated at a height of $1000 \mathrm{~m}$ using the Hybrid SingleParticle Lagrangian-Integrated Trajectory model (Draxler and Rolph, 2003).

Aerosols on the filter were digested with a mineral acid mixture $\left(30 \% \mathrm{HCl}+68 \% \mathrm{HNO}_{3}+38 \% \mathrm{HF}\right)$ at $160^{\circ} \mathrm{C}$ for $6 \mathrm{~h}$, after which the acids were evaporated to near dryness at $140^{\circ} \mathrm{C}$ to determine the total chemical compositions. The residue was dissolved in $2 \% \mathrm{HNO}_{3}$, and the total concentrations of $\mathrm{Na}, \mathrm{Mg}, \mathrm{Al}, \mathrm{Ca}, \mathrm{Mn}, \mathrm{Fe}, \mathrm{Cu}, \mathrm{Zn}$, and $\mathrm{Pb}$ in the aerosols were determined by inductively coupled plasma atomic emission microscopy (ICP-AES; SII NanoTechnology, Inc., SPS3500, Chiba, Japan), and those of V, Cr, and Ni by ICP-MS (Agilent 7700, Tokyo, Japan). All of the analyses were repeated three times to estimate the precision of our experiments. All of the bottles or beakers used were acidwashed before use.

\subsection{Water soluble components and leaching experiments}

Bulk chemical analysis of the water-soluble components (WSCs) in the aerosol was conducted using the procedure described by Furukawa and Takahashi (2011). Part of the filter was soaked in a Teflon beaker containing $0.10 \mathrm{~mL}$ of ethanol and $10 \mathrm{~mL}$ of Milli-Q (MQ) water. WSCs were leached by subjecting the solution to an ultrasonic treatment for $30 \mathrm{~min}$. The WSCs were then recovered as filtrate after filtration through a $0.20 \mu \mathrm{m}$ hydrophilic polytetrafluoroethylene (PTFE) filter. This extract was used to quantify major anions $\left(\mathrm{Cl}^{-}, \mathrm{NO}_{3}^{-}, \mathrm{SO}_{4}^{2-}\right.$, and $\left.\mathrm{C}_{2} \mathrm{O}_{4}^{2-}\right)$ by ion chromatography (IC7000, Yokogawa, Tokyo, Japan) equipped with a Shima-pack IC-SA1/-SA1(G) column. The eluent composition was $14 \mathrm{mM} \mathrm{NaHCO}$, and the flow rate of the eluent was $1.0 \mathrm{~mL} \mathrm{~min}^{-1}$. Part of the extracted solution was also used to determine the concentrations of water-soluble metal ions ( $\mathrm{Na}, \mathrm{Mg}, \mathrm{Al}, \mathrm{Ca}, \mathrm{Mn}, \mathrm{Fe}$, and $\mathrm{Zn}$ ) using the ICP-AES.
Furthermore, simulated seawater $[0.70 \mathrm{M} \mathrm{NaCl}$ at $\mathrm{pH} 8$ with $0.10 \mathrm{mM}$ ethylenediaminetetraacetic acid (EDTA) as an analogue of ligands in seawater] was used to determine the fraction of $\mathrm{Fe}$ that can be dissolved into the ocean. Iron dissolved in the simulated seawater at a temperature of $20^{\circ} \mathrm{C}$ for $24 \mathrm{~h}$ was determined by ICP-AES after filtration through a $0.20 \mu \mathrm{m}$ PTFE filter. The amount of Fe dissolved in MQ water was defined as MQ water-soluble $\mathrm{Fe}\left(\left[\mathrm{Fe}_{\mathrm{MQ}}\right]\right)$, whereas that in simulated seawater as seawater-soluble $\mathrm{Fe}\left(\left[\mathrm{Fe}_{\mathrm{SW}}\right]\right)$. The use of different leaching solutions, i.e., MQ water and simulated seawater, to determine the Fe solubility is helpful in understanding Fe dissolution and in estimating practical [ $\left.\mathrm{Fe}_{\mathrm{Sw}}\right]$ (Baker and Croot, 2010). Two results were determined to examine the fraction of soluble Fe:

$\left[\mathrm{Fe}_{\mathrm{Sol}}\right] /\left[\mathrm{Fe}_{\text {Total }}\right]=\left[\mathrm{Fe}_{\mathrm{MQ}}\right] /\left[\mathrm{Fe}_{\text {Total }}\right]$ or $\left[\mathrm{Fe}_{\mathrm{SW}}\right] /\left[\mathrm{Fe}_{\text {Total }}\right]$

where $\left[\mathrm{Fe}_{\text {Total }}\right]$ was determined by the acid digestion shown above. All of the analyses were repeated three times. All of the bottles or beakers used for the analyses were acid-washed before the experiments.

\subsection{XAFS measurements}

Iron K-edge XAFS was performed at beamline12C at the Photon Factory (Tsukuba, Japan) and the procedures of XAFS analyses were described by Takahashi et al. (2011). Most of the XAFS data for the aerosol samples were collected in December 2006. To prevent changes of the $\mathrm{Fe}$ species, the samples have been stored in a desiccator, since the reactions that can alter the species proceed in the presence of water. Therefore, it is not likely that original Fe species changed during the storage. To confirm the lack of an aging effect, we measured XANES for an aerosol sample (February sample) in June 2013. The two spectra shown in Fig. S1 were almost identical, suggesting that $\mathrm{Fe}$ species is not subject to change during the storage. XANES reflects the valence and symmetry of the element, whereas EXAFS yields 
the interatomic distance and coordination number. Combining the results of both XANES and EXAFS can make our speciation analysis more reliable (Furukawa and Takahashi, 2011). Transmission and fluorescence (FL) modes were employed to measure the Fe K-edge XANES and EXAFS data of the reference materials and samples, respectively. Aerosol samples were measured in the FL mode, where the sample was placed at a $45^{\circ}$ angle from the incident beam. The fluorescent X-rays were measured using a 19-element Ge solidstate detector. The fitting of the spectra of natural samples was conducted by linear combination fitting (LCF) of reference materials using a least squares fitting method performed via the REX2000 software (Rigaku Co., Ltd., Japan). The goodness-of-fit for the XANES spectra was estimated by defining the $R$ value in the energy region for the fitting as

$R=\sum\left(I_{\mathrm{S}}(E)-I_{\text {cal }}(E)\right)^{2} / \sum I_{\mathrm{S}}(E)^{2}$,

where $E$ is energy and $I_{\mathrm{S}}$ and $I_{\text {cal }}$ are the normalized absorption of the samples and calculated values, respectively. Energy calibration was performed by defining the pre-edge peak maximum of hematite $\left(\mathrm{Fe}_{2} \mathrm{O}_{3}\right)$ fixed at $7111 \mathrm{eV}$, and the energy range used for the fitting of the Fe K-edge XANES was from $7110 \mathrm{eV}$ to $7150 \mathrm{eV}$. Similarly, the $R$ value for EXAFS spectra was defined as

$R=\sum\left[k^{3} \chi_{\mathrm{s}}(k)-k^{3} \chi_{\mathrm{cal}}(k)\right]^{2} / \sum\left[k^{3} \chi_{\mathrm{s}}(k)\right]^{2}$.

The energy unit was transformed from $\mathrm{eV}$ to $\AA^{-1}$ to produce the EXAFS function $\chi(k)$, where $k$ is the photoelectron wave vector. The range of $k$ for the fitting of the $\mathrm{Fe} \mathrm{K}$-edge EXAFS was from $2.0 \AA^{-1}$ to $7.0 \AA^{-1}$. The precision of the relative ratios of each Fe species determined by the LCF was estimated to be better than $3 \%$, obtained from three independent scans and fitting procedure for the same aerosol sample (Takahashi et al., 2011). Supplementary data were also obtained at beamline BL01B1 using SPring-8 (Hyogo, Japan) and the spectra were identical to those measured at the Photon Factory. Standard materials used for fitting in this study were of analytical grade and were obtained from Wako Pure Chemical Industries, Ltd. (Osaka, Japan) or the Kanto Chemical Co., Inc. (Tokyo, Japan). Clay minerals were obtained from the Clay Mineral Society (Chantilly, USA).

\section{$2.4 \mu$-XRF mapping and $\mu$-XANES}

The XRF mapping of aerosol samples using an X-ray microbeam $(\sim 3 \mu \mathrm{m})$ was conducted at beamline 10.3.2 at the Advanced Light Source (ALS) in Lawrence Berkeley National Laboratory. The layout of beamline 10.3.2 at ALS was described by Marcus et al. (2004). The incident energy was fixed at $10 \mathrm{keV}$. The distributions of $\mathrm{S}, \mathrm{Cl}, \mathrm{K}, \mathrm{Ca}, \mathrm{V}, \mathrm{Mn}$, $\mathrm{Fe}$, and $\mathrm{Zn}$ were measured by mapping at a pixel size of $3 \times 3 \mu \mathrm{m}^{2}$ and a dwell time of $150 \mathrm{~ms}$. This mapping procedure showed us the ratios of the various elements in individual particle. These ratios are in turn related to the soluble Fe fraction ([$\left[\mathrm{Fe}_{\mathrm{sol}}\right] /\left[\mathrm{Fe}_{\text {total }}\right]$; Baker and Croot, 2010).
Based on the mapping, $\mu$-XAFS analysis on selected particles was conducted with a beam size of $3 \mu \mathrm{m} \times 3 \mu \mathrm{m}$. The energy range for the $\mu$-XAFS measurement was from $7010 \mathrm{eV}$ to $7500 \mathrm{eV}$, where the energy step was $1 \mathrm{eV}$. Other details of the analyses are similar to those reported by Manceau et al. (2002) and Marcus et al. (2004).

\section{Results and discussion}

\subsection{Characterization of aerosols}

\subsubsection{Backward trajectory analyses and concentration of aerosols}

Backward trajectory analyses suggest that the air masses in Tsukuba reflected typical seasonal trends in Japan (Fig. 1). The winter (December and February) and spring (March) samples were affected by the air masses from northeast China and megacities surrounding Tokyo, whereas spring (May) to summer (July to August) samples by the air masses from Pacific Ocean and the megacities and industrial areas around Tokyo. The sample in May is also affected by the air mass from northeast China. Origins of air masses in September and October were variously from northeast China, Pacific Ocean, and industrial areas around Tokyo.

The concentration of aerosols at Tsukuba was high in spring (February to May) and low in summer (August and September; Table 1). Considering aerosols in Tsukuba during spring are generally affected by Asian dust (Kanai et al., 2003), high aerosol concentration in spring possibly reflected the larger springtime contribution of Asian dust. Based on the backward trajectory analyses and concentration of aerosols, the following are suggested: (i) the air mass at Tsukuba was influenced by the anthropogenic activities around the sampling site throughout the year; and (ii) the ratio of anthropogenic aerosols relative to natural ones (Asian dust) is larger in summer.

\subsubsection{Chemical compositions of aerosols}

The chemical composition of the aerosols also reflected their sources. The concentration of non-sea salt (nss) sulfates was calculated as (Uematsu et al., 2010)

$$
\begin{aligned}
{\left[\text { nss-SO }_{4}^{2-}\right] } & =\left[\text { total } \mathrm{SO}_{4}^{2-}\right]_{\text {aerosol }}-\left(\left[\mathrm{SO}_{4}^{2-}\right] /\left[\mathrm{Na}^{+}\right]\right)_{\text {seawater }} \\
& \times\left[\mathrm{Na}^{+}\right]_{\text {aerosol }},
\end{aligned}
$$

where the ratio of $\left(\left[\mathrm{SO}_{4}^{2-}\right] /\left[\mathrm{Na}^{+}\right]\right)_{\text {seawater }}$ by Bruland and Lohan (2003) was used. The results showed that more than $98 \%$ of sulfate in the aerosol samples is nss sulfate, suggesting that most of the sulfate is of anthropogenic origin.

The sulfate and oxalate ion concentrations most likely originated from anthropogenic sources (Seinfeld and Pandis, 2006; Furukawa and Takahashi, 2011) were high from March to July. The major ion concentrations in aerosol were 

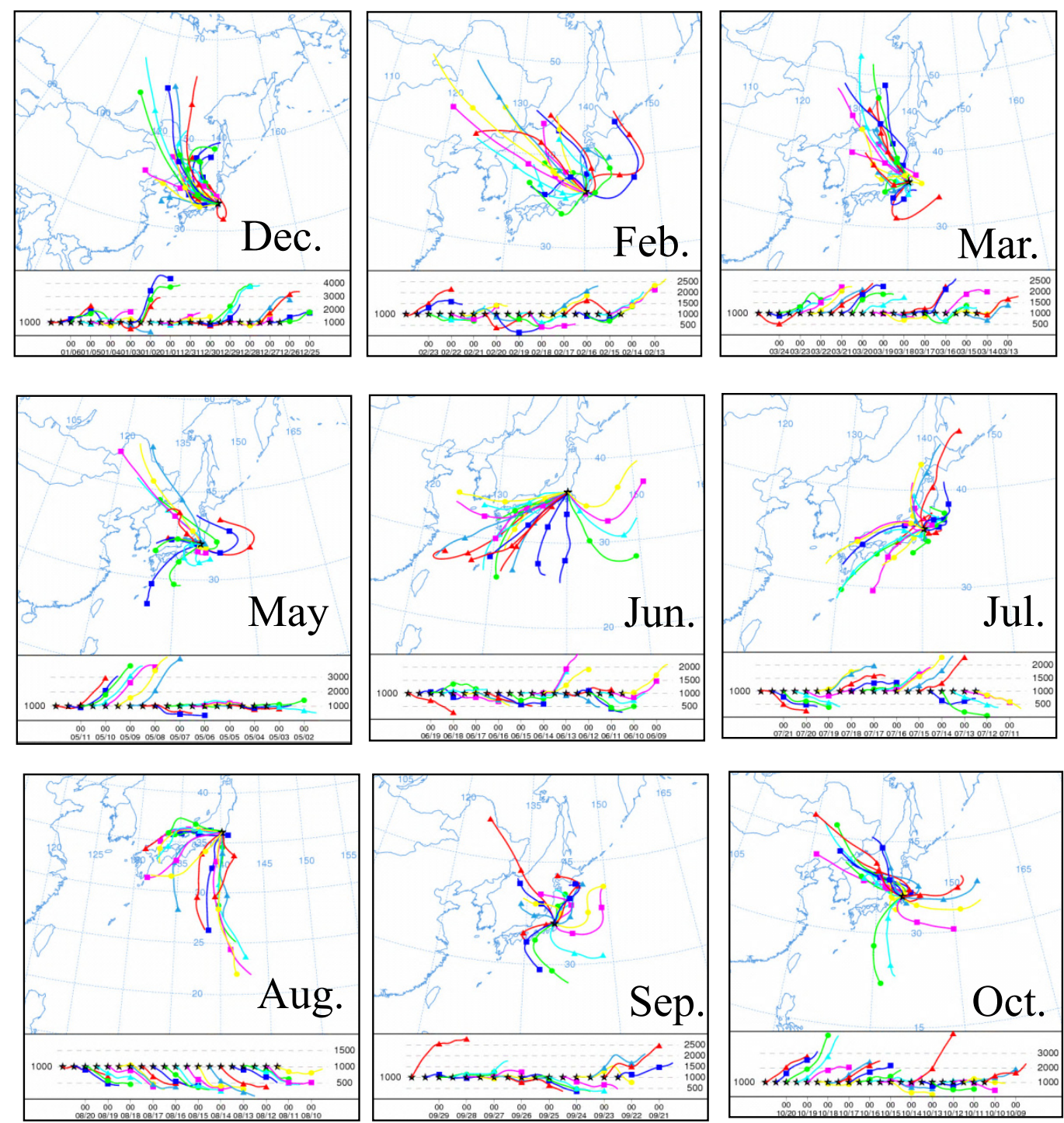

Fig. 1. Backward trajectory analyses at Tsukuba during the sampling for this study.

normalized by TSP to estimate the magnitude of the anthropogenic activity. The peaks of the sulfate and oxalate ion values normalized by TSP concentration were shifted to August compared with those without normalization (Fig. 2). This result suggests that the contribution of the aerosols from anthropogenic origins was relatively high from July to August, though the absolute concentrations of the anthropogenic components were high from March to July. Thus, this finding and the results of backward trajectory analyses coincide.

The concentration of total $\mathrm{Fe}\left(\left[\mathrm{Fe}_{\text {Total }}\right]\right)$ was high from March to June (approximately $900 \mathrm{ng} \mathrm{m}^{-3}$ ); intermediate in December, February, July, and October (ca. $400 \mathrm{ng} \mathrm{m}^{-3}$ to $600 \mathrm{ng} \mathrm{m}^{-3}$ ); and low in August and September (approximately $200 \mathrm{ng} \mathrm{m}^{-3}$; Fig. 3). Similar seasonal variations were also observed by Var et al. (2000). The high $\left[\mathrm{Fe}_{\text {Total }}\right]$ from
March to May was attributed to Asian dust coming from arid areas in Central China, such as the Gobi and Taklimakan deserts (Var et al., 2000; Kanai et al., 2003). The seasonal variation of $\mathrm{Al}$ was similar to that of $\left[\mathrm{Fe}_{\mathrm{Total}}\right]$ (Fig. 3). Aluminum comes mainly from crustal materials (Duce et al., 1980), implying that $\mathrm{Fe}$ in crust or soil is one of the main sources of the atmospheric Fe.

Some studies have suggested that $\mathrm{Fe}$ in road dust is one of the main sources of atmospheric Fe (e.g. Manoli et al., 2002). Pavements or asphalts in roads contain some minerals, such as quartz and hornblende, which can be released into the atmosphere as aerosol particles as pavements or asphalts wear (Kupiainen et al., 2003, 2005). Part of Fe in aerosols at Tsukuba possibly originated from road dust, such as pavement wear, as will be described in Sect. 3.2. 

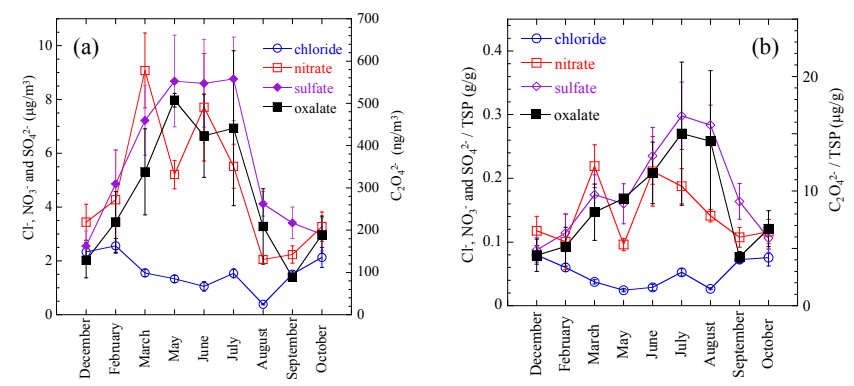

Fig. 2. (a) Concentrations of major anions in aerosol collected at Tsukuba; (b) concentrations of major anions at Tsukuba normalized by TSP concentration. The values are tabulated in Table S1. Error bars are standard deviations obtained by three independent experiments.

\subsubsection{Enrichment factor of each element}

The value of enrichment factor (EF) relative to the crust of the earth is used to identify the source of each element. The $\mathrm{EF}$ of an element $M$ is defined as

$\mathrm{EF}=(M / \mathrm{Al})_{\text {aerosol }} /(M / \mathrm{Al})_{\text {crust }}$,

where $(M / \mathrm{Al})_{\text {crust }}$ is as described by Taylor (1964). The EFs of $\mathrm{Zn}, \mathrm{Cu}$, and $\mathrm{Pb}$ exceeded 10 for all the seasons (Fig. 4a), suggesting that these metals originated mainly from anthropogenic sources and that aerosols in Tsukuba were affected by anthropogenic activities throughout the year. In particular, EFs of $\mathrm{Zn}$ and $\mathrm{Cu}$ during summer (July and August) were higher than those for the other seasons (Fig. 4a). Thus, the influence of anthropogenic activities was relatively larger in this period. This result is consistent with backward trajectory analyses that showed the influence of air masses from industrial areas surrounding Tokyo during these months.

On the other hand, the EFs of other metals $(\mathrm{Na}, \mathrm{Mg}, \mathrm{Ca}, \mathrm{V}$, $\mathrm{Cr}, \mathrm{Mn}, \mathrm{Fe}$, and $\mathrm{Ni}$ ) were relatively lower (Fig. 4a). These elements are presumably suspended and transported from natural sources such as crust or soil. Sodium, which is abundant in sea-salt particles, has relatively higher EF values, above 1 , suggesting that aerosols at Tsukuba contain some sea salt components (Furukawa and Takahashi, 2011).

EFs of $\mathrm{V}$ and $\mathrm{Ni}$, which are trace elements in fossil fuel combustion, showed a definitive seasonal trend of peaking during summer (Fig. 4b). This seasonal trend indicated that atmospheric $\mathrm{V}$ and $\mathrm{Ni}$ are emitted by oil combustion, particularly during summer. Some studies (Sedwick et al., 2007; Sholkovitz et al., 2010) showed that $\left[\mathrm{Fe}_{S o l}\right]$ or $\left[\mathrm{Fe}_{\mathrm{Sol}}\right] /\left[\mathrm{Fe}_{\text {Total }}\right]$ in aerosols is related to oil combustion, details of which will be described in Sect. 3.3. In Japan, oil is mainly used for the generation of electricity, and some electric power plants using oil are located around Tokyo Bay, which is the pathway of air masses in Tsukuba during the summer (Fig. 1).

\subsection{XAFS results}

Iron K-edge XAFS measurements were performed to identify the chemical species in aerosols. Figure 5a shows the XANES spectra of aerosol samples with the fitting results, whereas the spectra of various reference materials of $\mathrm{Fe}$ are shown in Fig. S2a (Supplement). The fractions of Fe species determined by XANES are shown in Fig. 6. The XANES spectra of aerosol samples collected in various months are similar to one another. The $\mathrm{Fe}$ (III) fraction of the total $\mathrm{Fe}$ in aerosol as determined by the pre-edge position around $7110 \mathrm{keV}$ (Wilke et al., 2001; Marcus et al., 2008) was almost constant at approximately $70 \%$ throughout the year. However, a shift of the peak in the XANES region from $7128 \mathrm{eV}$ to $7129.5 \mathrm{eV}$ was observed for the sample collected, especially in June, July, and August. The difference can be also observed in the derivative XANES spectra (Fig. 5b), where positive $(7133.8 \mathrm{eV}$ and $7139.9 \mathrm{eV})$ and negative $(7136.7 \mathrm{eV})$ peaks were clearly seen in the derivative spectra of June, July, and August (Fig. 5b). These results suggest that Fe species, or the relative ratios of various Fe species in June, July, and August are different from those of other months.

In the LCF analysis, the results with $R$ values less than $0.02(\%)$ can be assumed as good fitting (Léon et al., 2004; Shukla et al., 2004), suggesting that the end-members of $\mathrm{Fe}$ species employed in the fitting are reasonable. Based on our XANES results (Fig. 5), the main Fe species in aerosols at Tsukuba were found to be illite, ferrihydrite, hornblende, and $\mathrm{Fe}$ (III) sulfate $\left[\mathrm{Fe}_{2}\left(\mathrm{SO}_{4}\right)_{3} \cdot n \mathrm{H}_{2} \mathrm{O}(n=6\right.$ to 9$\left.)\right]$. The $R$ value of each fitting result was less than 0.010. LCF of the XANES spectra for clay minerals such as chlorite and smectite or illite and magnetite cannot explain the sample spectra, considering the $R$ values were relatively large ( 0.045 and 0.037 , respectively) in the fitting (Fig. S2b and c), which reinforces our results that the $\mathrm{Fe}$ main species in the aerosols are illite, ferrihydrite, hornblende, and Fe(III) sulfate. Significant fractions of ferrihydrite and hornblende ( $>20 \%$ of total Fe) were observed in all of the aerosol samples.

Additionally, the EXAFS fittings for all the aerosol samples were conducted with the same Fe species determined by XANES (Fig. 7), for which the EXAFS spectra of the standard materials shown in Fig. S3 were employed. If we could obtain similar information on the Fe species by fitting both by XANES and EXAFS, the speciation data can be more reliable, because EXAFS spectra reflect different information from XANES, such as neighboring atoms, interatomic distances, and coordination number for the chemical species. The fitting results of EXAFS (Fig. 6) are very similar to those obtained with the XANES fitting, showing that the Fe species estimated in this study can be robust. We found that we can use four species to fit the spectra for all the samples examined, namely, illite, ferrihydrite, hornblende, and Fe(III) sulfate. 

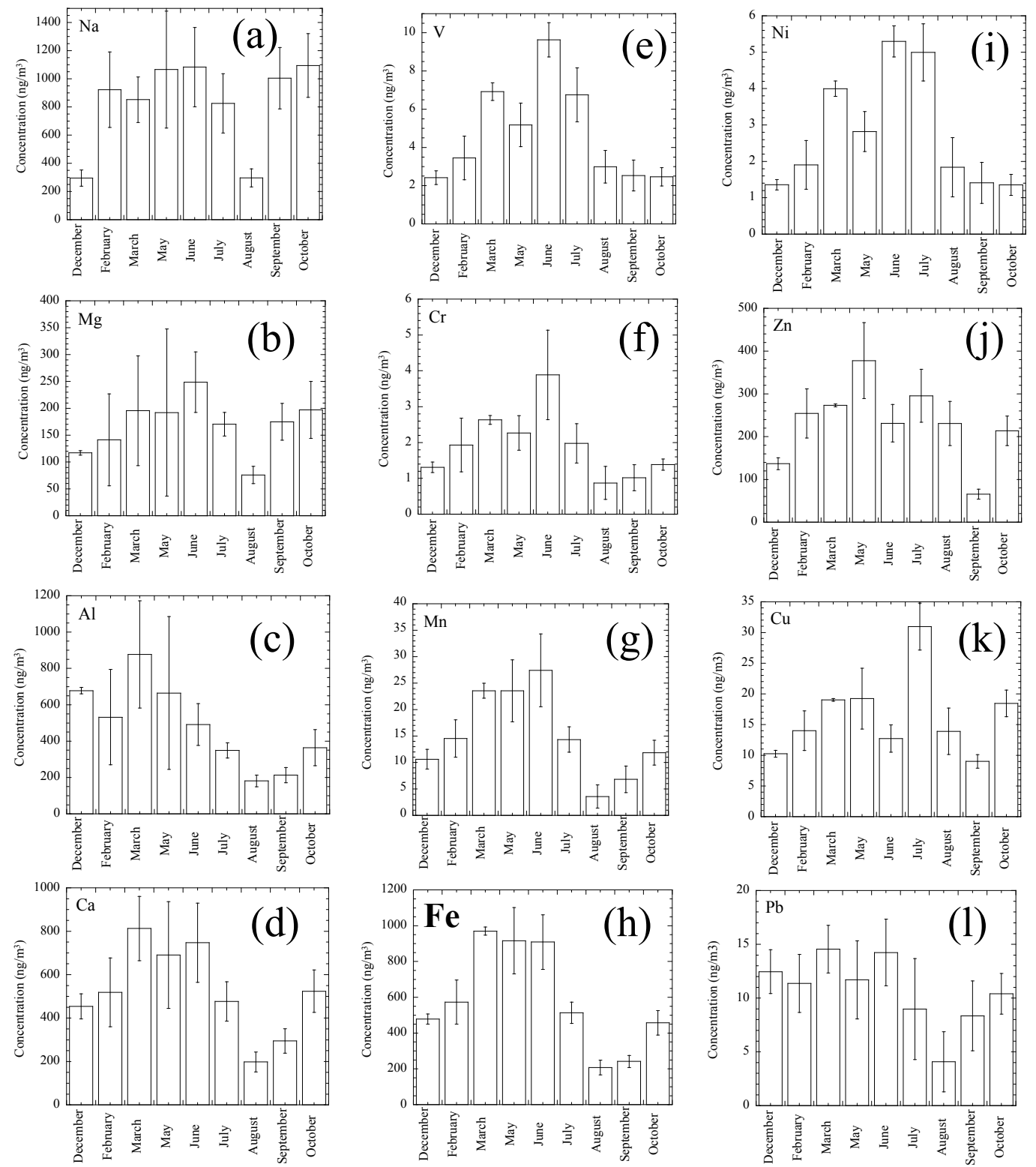

Fig. 3. Concentration of various metal ions in aerosol collected at Tsukuba. (a) sodium (Na), (b) magnesium (Mg), (c) aluminum (Al), (d) calcium (Ca), (e) vanadium (V), (f) chromium $(\mathrm{Cr}),(\mathbf{g})$ manganese $(\mathrm{Mg}),(\mathbf{h})$ iron $(\mathrm{Fe}),(\mathbf{i})$ nickel $(\mathrm{Ni}),(\mathbf{j})$ zinc $(\mathrm{Zn}),(\mathbf{k})$ copper $(\mathrm{Cu})$, and (l) lead $(\mathrm{Pb})$. Error bars are standard deviations obtained by three independent experiments.

The validity of the number of end members can be confirmed by the principal component analysis (PCA; Beauchemin et al., 2002; Seiter et al., 2008). For the PCA and target transformation analysis in the present study, SIXPack data analysis software (www.ssrl.slac.stanford.edu/swebb/ sixpack.htm) was used. PCA determines the minimum number of significant components required to fit the sample spectra. The results of the PCA analysis are shown in Fig. S4, in which the contributions of four components were sufficient to explain the spectrum of our samples, which also support the fitting results above.

\subsection{Main Fe species in aerosols}

\subsection{1 $\quad \mathrm{Fe}($ III) sulfate}

$\mathrm{Fe}(\mathrm{III})$ sulfate is an important component in terms of its influence on marine primary production due to its high solubility $(440 \mathrm{~g} / 100 \mathrm{~g}$ water; David, 1994). Schroth et al. (2009) showed that $\mathrm{Fe}$ emitted from oil combustion, determined by XAFS, is $\mathrm{Fe}(\mathrm{III})$ sulfate (72\%) and ferrihydrite $(28 \%)$ and that Fe in oil fly ash is highly soluble. The presence of $\mathrm{Fe}(\mathrm{III})$ sulfate in industrial aerosols was also implied by Xie 


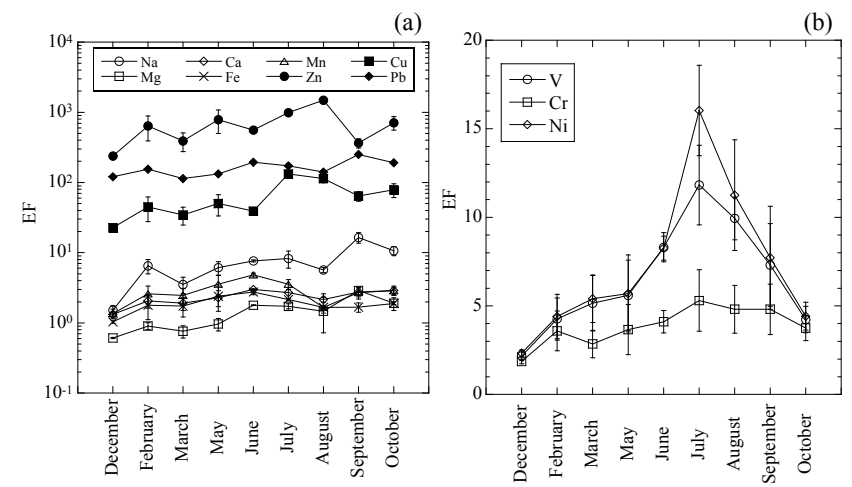

Fig. 4. Enrichment factor (EF) of each element in aerosol at Tsukuba for (a) $\mathrm{Na}, \mathrm{Mg}, \mathrm{Ca}, \mathrm{Fe}, \mathrm{Mn}, \mathrm{Zn}, \mathrm{Cu}$, and $\mathrm{Pb}$; (b) EFs of $\mathrm{V}, \mathrm{Cr}$, and Ni. Error bars are standard deviations obtained by three independent experiments.

et al. (2005) by scanning electron microscopy and by Oakes et al. (2012b) by Fe K-edge XANES.

Thus, the Fe(III) sulfate in our aerosol samples also possibly originated from oil combustion. Iron(III) sulfate was the main Fe species found from May to August. On the other hand, the air mass at Tsukuba during this period was strongly affected by anthropogenic activities, as confirmed by (i) the backward trajectory analyses, (ii) high concentrations of anthropogenic ions (sulfate and oxalate), and (iii) large EFs of $\mathrm{V}$ and $\mathrm{Ni}$ which are indicators of fossil fuel combustion (Chen et al., 2004; Jang et al., 2007; Sholkovitz et al., 2009). Thus, $\mathrm{Fe}(\mathrm{III})$ sulfate is mainly found in aerosols during the peak of anthropogenic activities, especially oil combustion.

In addition, Fe species before and after the water extraction treatment for the July sample were examined by XANES fitting to confirm the presence of Fe(III) sulfate (Fig. S5). The main $\mathrm{Fe}$ species in aerosol before extraction were $\mathrm{Fe}(\mathrm{III})$ sulfate $(23 \%)$, ferrihydrite (48\%), and hornblende (29\%) $(R=0.009)$, whereas those after the extraction were ferrihydrite $(70 \%)$ and hornblende $(30 \%)(R=0.009)$. This change in the main Fe species with the addition of water supports the presence of $\mathrm{Fe}(\mathrm{IIII})$ sulfate in aerosols, which is readily dissolved into water. Figure S5 shows the comparison of the XANES derivative spectra for the July sample before and after the water extraction. The derivative spectrum after water extraction was slightly changed because of the selective dissolution of Fe(III) sulfate into the solution. The spectrum after water extraction was more similar to that of ferrihydrite, whereas that before extraction was similar to Fe(III) sulfate. These facts also support the presence of $\mathrm{Fe}(\mathrm{III})$ sulfate in our July sample.

We measured the XANES spectra of the standard material mixed with different mole ratios to confirm the accuracy of the fraction of $\mathrm{Fe}$ (III) sulfate determined by XANES fitting. Mole ratio of $\mathrm{Fe}(\mathrm{III})$ sulfate and ferrihydrite was adjusted to $1: 9$ (A), 2:8 (B), and 3:7 (C), as shown in Fig. S6a. The
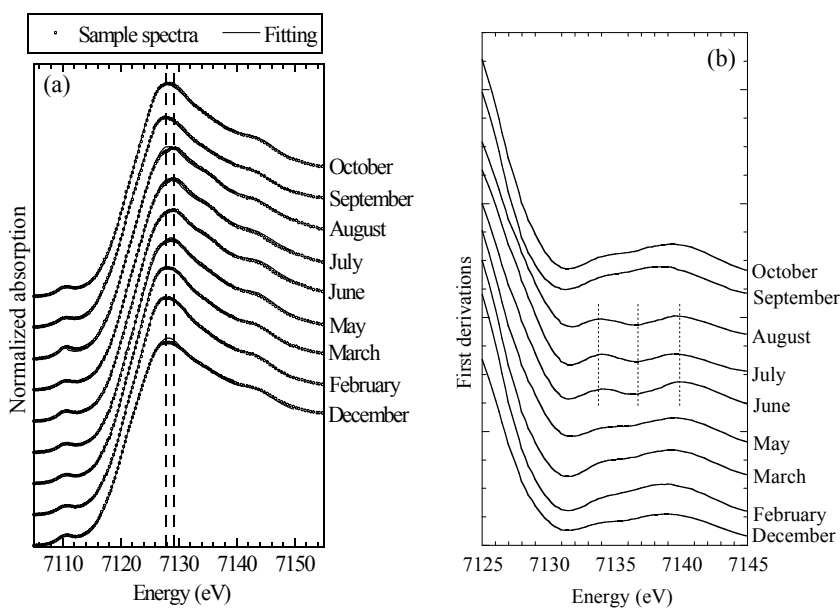

Fig. 5. (a) Fitting of Fe K-edge XANES spectra for aerosols collected at various months and (b) their first derivative spectra.

results showed that XANES fitting is reliable in obtaining the fraction of $\mathrm{Fe}$ (III) sulfate within a $2 \%$ error if it is in such a binary system. The variation in derivative spectra for mixed standard materials with different $\mathrm{Fe}$ (III) sulfate/ferrihydrite ratios was also measured (Fig. S7b). This variation is similar to what we observed in the natural samples using water extraction in Fig. S6.

A $\mu$-XANES result for a spot with high signals of $\mathrm{Fe}, \mathrm{S}$, and $\mathrm{V}$ with a relatively low signal of $\mathrm{K}$ (Fig. 8) indicated the presence of $\mathrm{Fe}$ (III) sulfate and ferrihydrite and the absence of clay minerals in the spot. The high $\mathrm{V}$ count implies that the particle originated from oil combustion, which also supports that $\mathrm{Fe}$ (III) sulfate can be of the same origin (Sedwick et al., 2007; Schroth et al., 2009). Iron sulfides such as pyrite, pyrrhotite, or mackinawite also consist of $\mathrm{Fe}$ and $\mathrm{S}$, but the XANES spectra of Fe sulfides should have the absorption edge at a lower energy, which are quite different from the observed spectrum (Figs. S2a and 8). Thus, the Fe species in the particle containing $\mathrm{Fe}$ and $\mathrm{S}$ shown in Fig. 8 is not $\mathrm{Fe}$ sulfide but $\mathrm{Fe}(\mathrm{III})$ sulfate, coexistent with ferrihydrite.

\subsubsection{Ferrihydrite}

Ferrihydrite is one of the main Fe hydroxides in soil (Jambor and Dutrizac, 1998). The source of atmospheric ferrihydrite can be the soil around the sampling site. Some ferrihydrite in aerosols can also be formed by acid processing in the atmosphere (e.g. Shi et al., 2009; Takahashi et al., 2011) especially during dust storm season (spring in East Asia). However, whether ferrihydrite in our aerosol samples was formed by the precipitation of ferrihydrite in aerosols resulting from acid processing or not was unclear in this study. Most of the ferrihydrite possibly originated from soil, because ferrihydrite was found in our samples for all seasons.

Some reports using XAFS indicated that the main $\mathrm{Fe}$ hydroxide species in aerosol are goethite, magnetite, or 

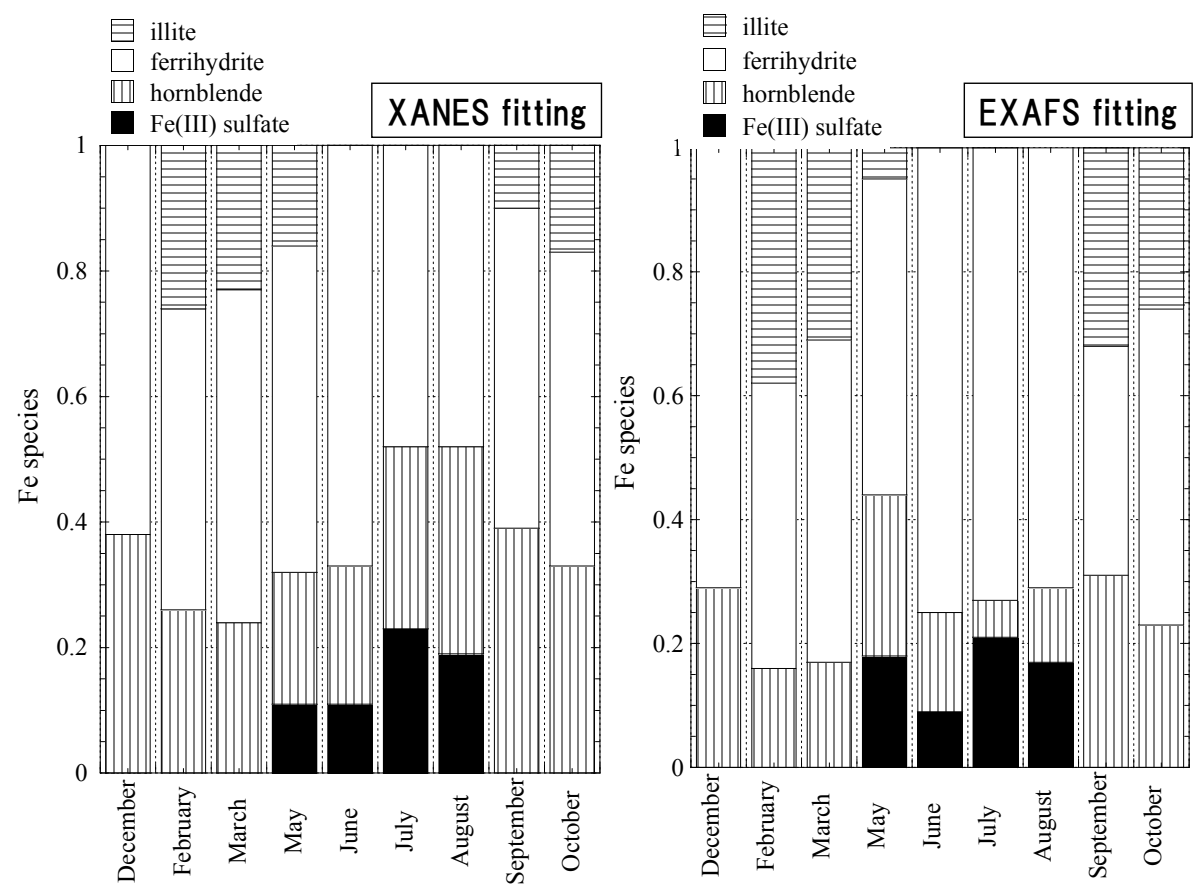

Fig. 6. Iron species in aerosols estimated by (a) XANES fitting and (b) EXAFS fitting.
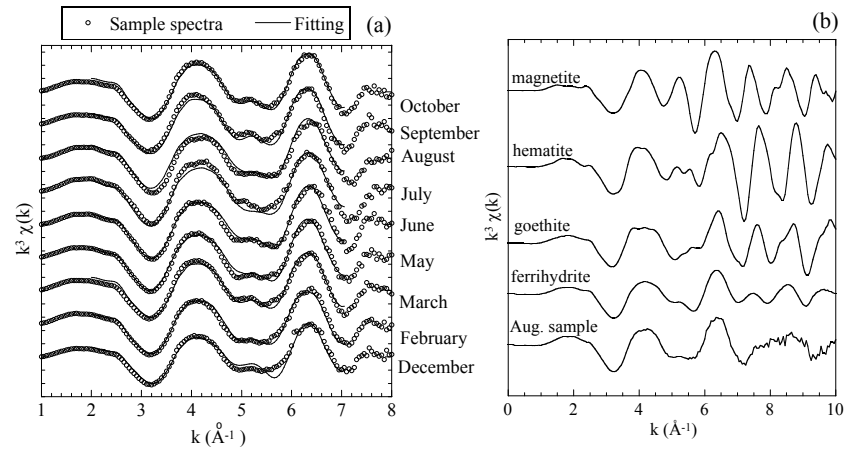

Fig. 7. (a) Fitting of Fe K-edge EXAFS spectra in $k$ space for aerosols collected at various months with (b) the reference spectra for various $\mathrm{Fe}$ oxide species.

hematite (Oakes et al., 2012a, b). However, Fe oxide in our samples was suggested to be mainly ferrihydrite, though small amounts of goethite, magnetite, and hematite lower than the detection limit of XAFS can coexist in our samples. Considering that the shape of the XANES spectrum of ferrihydrite is similar to that of goethite or hematite to some degree, identifying the $\mathrm{Fe}$ oxide in aerosol, whether as ferrihydrite or other Fe hydroxide species, is difficult by XANES fitting. Consequently, EXAFS was also employed in this study to identify the Fe hydroxide species. Ferrihydrite is less crystalline than the other Fe oxides (Jambor and Dutrizac, 1998), the degree of which is shown in the EXAFS spectra of each species (Fig. 7b). Thus, the amplitude of the
EXAFS oscillations of ferrihydrite is lower than that of, for instance, goethite. The oscillations of the EXAFS spectra of the aerosol samples (Fig. 7a) were also small as we found for ferrihydrite, suggesting that the $\mathrm{Fe}$ hydroxide in aerosol can be mainly ferrihydrite (Jambor and Dutrizac, 1998). Similar results were also reported in Schroth et al. (2009) and Takahashi et al. (2011).

\subsubsection{Hornblende and illite}

Hornblende is present in asphalt (Kupiainen et al., 2003, 2005). Hornblende suspended from road dust may be present in the aerosols collected in Tsukuba. Iron species in road dust collected in a tunnel in Hiroshima Prefecture (Japan) were identified by XAFS fitting to demonstrate the presence of hornblende in aerosols. Figure 9 shows the results of XAFS analysis for the road dust aerosol samples. The result of XANES fitting (Fig. 9a) suggest that the main Fe species in the road dust were hornblende (35\%) and ferrihydrite $(65 \%$; $R=0.009$ ). Similar results (hornblende:ferrihydrite $=37$ : 63) were also obtained by EXAFS analysis (Fig. 9b). The spectra of road dust cannot be fitted by the LCF of other end members such as ferrihydrite and illite $(R=0.057)$, ferrihydrite and chlorite $(R=0.023)$, or ferrihydrite and magnetite $(R=0.019)$ as shown in Fig. 9c. These results revealed that hornblende can be one of the main $\mathrm{Fe}$ species in road dust, supporting the suggestion above that hornblende from pavement wear is possibly one of the $\mathrm{Fe}$ species found in aerosols. Additionally, Fe pre-edge analyses showed that the fraction of ferrous to total $\mathrm{Fe}$ was approximately $30 \%$, which 
(a)
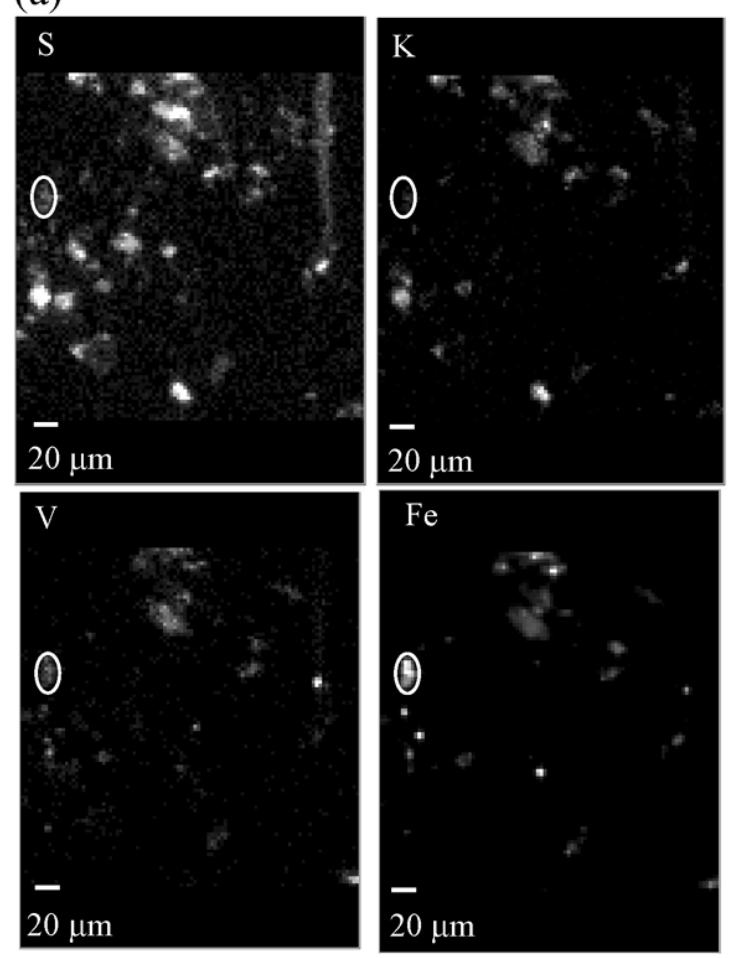

(b)

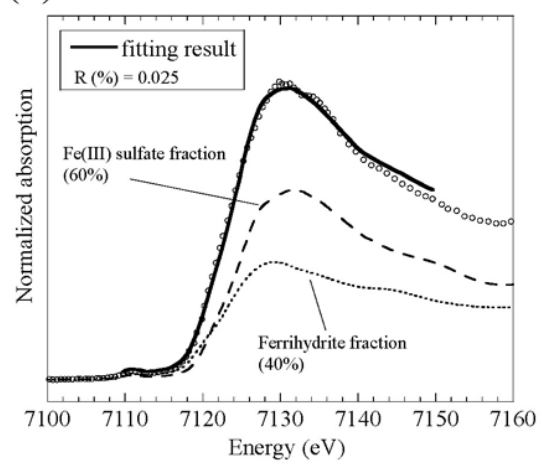

Fig. 8. (a) Micro-XRF mapping of $S, K, V$, and Fe for aerosol samples dispersed in a Kapton filter for the sample collected in July and (b) Fe K-edge XANES for the spot indicated with a circle in (a).

is attributed to the presence of hornblende, considering hornblende contains ferrous ions in crystalline form (Schroth et al., 2009). The presence of hornblende is also reported in Oakes et al. (2012b).

As for the fourth $\mathrm{Fe}$ species suggested in this study, $\mathrm{Fe}$ in illite is expected, given that illite is a common clay mineral in soils or desert dust and often found in atmospheric aerosols from natural sources (Claquin et al., 1999; Takahashi et al., 2011). Thus, illite was likely present in our aerosol samples, as suggested by the XANES and EXAFS analysis (Figs. 57). In terms of the Fe content of the ocean, the amount of clay minerals such as illite in aerosols is a critical factor controlling Fe solubility (Journet et al., 2008). However, this factor may not be important at least for our samples, as will be described in the next section.

Consequently, the spectra of $\mathrm{Fe}$ in our aerosol samples can be well fitted by the linear combination of illite, ferrihydrite, hornblende, and $\mathrm{Fe}$ (III) sulfate, which were also employed to fit the EXAFS of our samples. The relative contributions of the four species determined by the EXAFS fitting (Figs. 6b and 7) are similar to those obtained by XANES, showing the validity of our XANES and EXAFS interpretation, as indicated above.

\subsection{Atmospheric concentrations of soluble $\mathrm{Fe}$ and fraction of soluble $\mathrm{Fe}$}

In this study, we aimed to understand the dependence of the fraction of soluble $\mathrm{Fe}$ on the $\mathrm{Fe}$ species as determined by XAFS analysis. The atmospheric concentrations, $\left[\mathrm{Fe}_{\mathrm{MQ}}\right]$ and [Fesw], obtained through leaching experiments were determined in this study, which showed clear seasonal variations. The former varied from $7 \mathrm{ng} \mathrm{m}^{-3}$ to $95 \mathrm{ng} \mathrm{m}^{-3}$, and the latter from $52 \mathrm{ng} \mathrm{m}^{-3}$ to $201 \mathrm{ng} \mathrm{m}^{-3}$ (Fig. 10a). The soluble Fe concentrations in both solutions were high from May to July. These results confirmed the presence of Fe that is readily soluble even in MQ water. Furthermore, this seasonal variation was correlated with those of concentrations of anthropogenic components such as sulfate or oxalate (Fig. 11), for which the correlation coefficients $\left(r^{2}\right)$ of the concentrations of sulfate and oxalate with that of $\mathrm{Fe}_{\mathrm{MQ}}$ were 0.853 and 0.905 , respectively. This result suggests that the fraction of soluble $\mathrm{Fe}$ is supplied mainly by anthropogenic sources.

The fraction of soluble Fe obtained by MQ water leaching $\left(=\left[\mathrm{Fe}_{\mathrm{MQ}}\right] /\left[\mathrm{Fe}_{\text {Total }}\right]\right)$ and SW leaching $\left(=\left[\mathrm{Fe}_{\mathrm{SW}}\right] /\left[\mathrm{Fe}_{\text {Total }}\right]\right)$ were $1.4 \%$ to $17 \%$ and $11 \%$ to $34 \%$, respectively, for the aerosol samples in Tsukuba, which also showed seasonal variations (Fig. 10b). The fraction of soluble $\mathrm{Fe}$ is high from May to August (especially in July and August), and relatively lower in the other months. The aerosol with a high soluble 


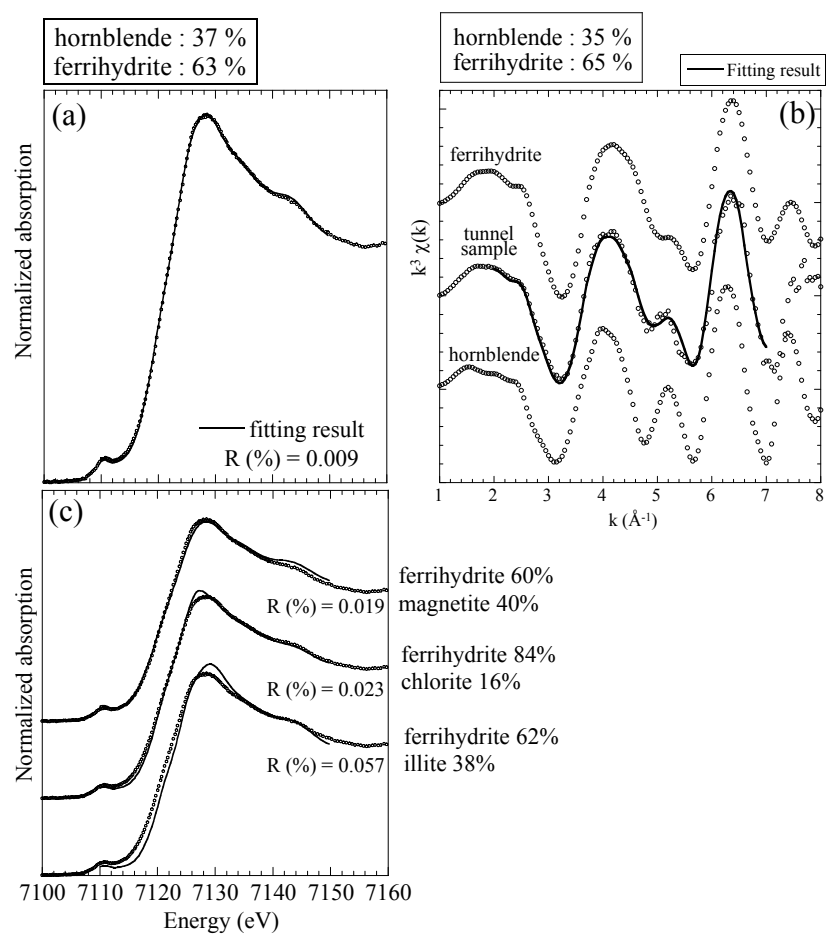

Fig. 9. (a) Iron K-edge XANES and (b) EXAFS for the sample collected in Yasumiyama Tunnel fitted by the spectra of hornblende and ferrihydrite. Examples of fitting by other Fe species are shown in (c).
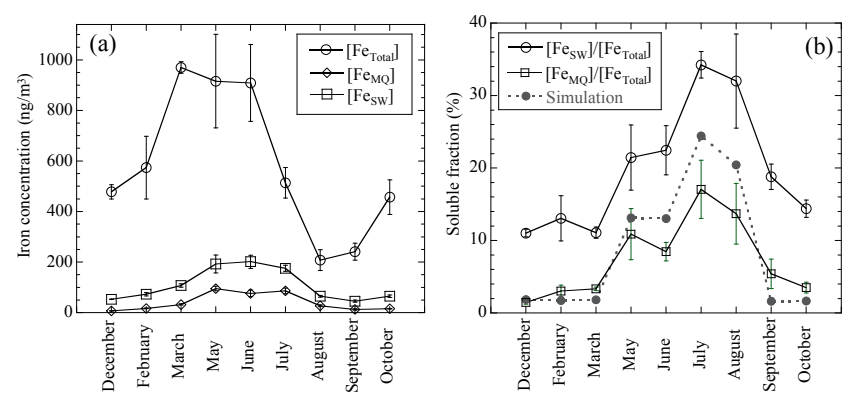

Fig. 10. (a) Concentrations of total $\mathrm{Fe}$ and Fe soluble in Milli-Q (MQ) water and simulated seawater (SW) noted as $\left[\mathrm{Fe}_{\mathrm{MQ}}\right]$ and $\left[\mathrm{Fe}_{S W}\right]$, respectively. The values are tabulated in Table S2. (b) Soluble Fe fractions determined using the MQwater and SW extractions, noted as $\left[\mathrm{Fe}_{\mathrm{MQ}}\right] /\left[\mathrm{Fe}_{\mathrm{Total}}\right]$ and $\left[\mathrm{Fe}_{\mathrm{SW}}\right] /\left[\mathrm{Fe}_{\mathrm{Total}}\right]$, respectively. Simulated results for $\left[\mathrm{Fe}_{\mathrm{SW}}\right] /\left[\mathrm{Fe}_{\mathrm{Total}}\right]$ assuming the apparent solubilities of ferrihydrite, illite, $\mathrm{Fe}$ (III) sulfate, and hornblende were also included. Error bars are standard deviations obtained by three independent experiments.

Fe fraction in this period is possibly related to the influence of anthropogenic activities on the chemical characteristics of the aerosols (Figs. 1-4). As a result, the seasonal variation of the soluble Fe fraction is strongly correlated with Fe species, as determined by XAFS fitting. In fact, the fraction shown in Fig. $10 \mathrm{~b}$ is similar to the ratio of $\mathrm{Fe}(\mathrm{III})$ sulfate to total $\mathrm{Fe}$
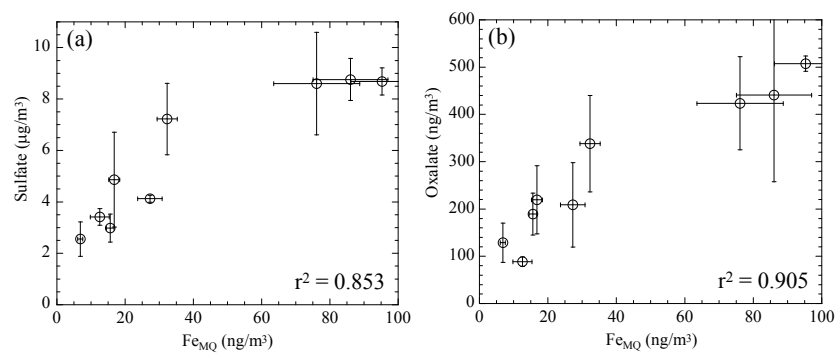

Fig. 11. Relationships of sulfate and oxalate concentrations with atmospheric soluble $\mathrm{Fe}\left(\left[\mathrm{Fe}_{\mathrm{MQ}}\right]\right)$. Error bars are standard deviations obtained by three independent experiments.

(Fig. 6), suggesting that the presence of $\mathrm{Fe}(\mathrm{III})$ sulfate can increase the fraction of soluble Fe. Thus, the Fe(III) sulfate concentration is an important factor controlling the extent of Fe dissolution in seawater.

The soluble Fe fraction was simulated in synthetic seawater to confirm the effect of sulfate. The simulation was based on the assumption that soluble Fe fractions in the simulated seawater employed in this study for each $\mathrm{Fe}$ species were $2.6 \%$ for ferrihydrite (Takahashi et al., 2011), $0.6 \%$ for illite (Takahashi et al., 2011), $100 \%$ for $\mathrm{Fe}(\mathrm{III})$ sulfate (assumption made in this study), and $0 \%$ for hornblende (assumption made in this study). As a result, the trend of the simulation curve for $\left[\mathrm{Fe}_{\mathrm{SW}}\right] /\left[\mathrm{Fe}_{\text {Total }}\right]$ shown in Fig. 10b is similar to that of the experimental value of $\left[\mathrm{Fe}_{\mathrm{SW}}\right] /\left[\mathrm{Fe}_{\text {Total }}\right]$, although the absolute values of the two systems differed to some degree. The discrepancy can be due to the different particle sizes of the soluble Fe species between the aerosol samples and minerals (ferrihydrite and illite) employed in the leaching experiments. However, the similarity of the calculated and experimental curves also indicated that the soluble fraction is strongly affected by the $\mathrm{Fe}(\mathrm{III})$ sulfate fraction in the aerosols (Fig. 6).

The difference between $\left[\mathrm{Fe}_{\mathrm{MQ}}\right] /\left[\mathrm{Fe}_{\text {Total }}\right]$ and $\left[\mathrm{Fe}_{\mathrm{SW}}\right] /\left[\mathrm{Fe}_{\text {Total }}\right]$ (8\% to $\left.17 \%\right)$ was observed in every sample (Fig. 10a). The ligand (EDTA) in simulated seawater contributed to the increase in the amount of soluble $\mathrm{Fe}$, because ferrihydrite can be dissolved into water containing ligands that stabilize $\mathrm{Fe}$ in the aqueous phase (Kraemer, 2004; Takahashi et al., 2011). Thus, the increase of the solubility was possibly caused by the dissolution of ferrihydrite, which was also pointed out by Aguilar-Islas et al. (2010). The presence of ferrihydrite is also important due to the reactivity of ferrihydrite with organic ligands (siderophores) in the ocean (Takahashi et al., 2011) to consider the effect of uptake of Fe by phytoplankton. Here, we employed EDTA to simulate the process in seawater, since the stability constants of $\mathrm{Fe}$ (III)-EDTA complex are similar to those of (i) $\mathrm{Fe}$ siderophore complexes (Witter et al., 2000; Hasegawa et al., 2004) and (ii) Fe-humic substance complexes (Takahashi et al., 1997) that can be present in seawater. One may think that the concentration of EDTA used in this experiment is too 
high. However, EDTA was primarily added in the leaching water to keep Fe in the solution and to avoid reprecipitation of $\mathrm{Fe}$ in the solution before measurement of the dissolved $\mathrm{Fe}$. On the other hand, the amount of aerosol relative to that of water is also very high in the experiments compared with that in the natural system. Thus, we think that the absolute concentration of EDTA is not very important, but sufficient amount of EDTA is necessary to determine the amount of soluble $\mathrm{Fe}$ in the aerosols.

Oxalate leached from aerosol to MQ water can also contribute to the increase in $\left[\mathrm{Fe}_{\mathrm{MQ}}\right]$ such as by photoreductive dissolution and complexation of oxalate with $\mathrm{Fe}$ (Paris et al., 2011). The effect of photoreductive dissolution cannot be discussed here, since we did not control this factor in our leaching experiments. If oxalate complexation can contribute to the increase in $\left[\mathrm{Fe}_{\mathrm{MQ}}\right]$, the molar ratio of oxalate to $\mathrm{Fe}_{\mathrm{MQ}}$ should be constant, considering that the mole concentrations of total $\mathrm{Fe}$ in aerosol were higher than that of oxalate in all months except for August (Fig. S6). More importantly, the molar ratios of oxalate to $\mathrm{Fe}_{\mathrm{MQ}}$ in the leaching solution were systematically larger than 3.2 (Fig. S7). If oxalate complexation is a dominant factor for the dissolution of $\mathrm{Fe}$, the molar ratio should be less than three, since the ratio of $\mathrm{Fe}$-oxalate in water (= [oxalate]:[Fe]) can be from $1: 1$ to $3: 1$ based on the stability constants of $\mathrm{Fe}(\mathrm{II})$ - and $\mathrm{Fe}(\mathrm{III})$-oxalate complexes (Martell and Smith, 1977). Thus, oxalate complexation cannot be a primarily important factor of $\left[\mathrm{Fe}_{\mathrm{MQ}}\right]$, but the correlation between [oxalate] and $\left[\mathrm{Fe}_{\mathrm{MQ}}\right]$ in leaching solution suggests that the oxalate complexation can enhance the dissolution of $\mathrm{Fe}$ to the aqueous phase.

It is also suggested that $\mathrm{pH}$ of the solution can be also important for the dissolution of Fe into water (e.g., Desboeufs et al., 1999). It was clear that $\mathrm{pH}$ values were low for the three samples in this study (May, June, and July), which also showed high $\left[\mathrm{Fe}_{\mathrm{MQ}}\right]$, possibly due to the large amount of acidic species such as sulfate and nitrate. The presence of a large amount of sulfate may be related to the presence of Fe(III) sulfate during the period. Thus, we can conclude that the speciation of Fe, which is also linked to acidity of the samples, can be an important controlling factor of the $\left[\mathrm{Fe}_{\mathrm{MQ}}\right]$.

Anthropogenic effects on the amount of soluble Fe fraction found in this study were also observed in other studies (Majestic et al., 2007; Sholkovitz et al., 2009; Kumar and Sarin, 2010). However, the details of the Fe speciation in aerosols were unclear in these studies. The soluble $\mathrm{Fe}$ fraction determined in this study coupled with the Fe speciation information allows us to prove that the relative amount of $\mathrm{Fe}$ (III) sulfate is responsible for the variation in the soluble fraction of $\mathrm{Fe}$ in the aerosols.

The EFs of V and Ni were highest from July to August, when soluble Fe amount was large (Fig. 4b) and where the $r^{2}$ values between $\mathrm{Fe}_{\mathrm{MQ}}$ and $\mathrm{V}$ or Ni were respectively high (Fig. 12). This result is reasonable because Fe(III) sulfate can originate from oil combustion (Schroth et al., 2009), and V
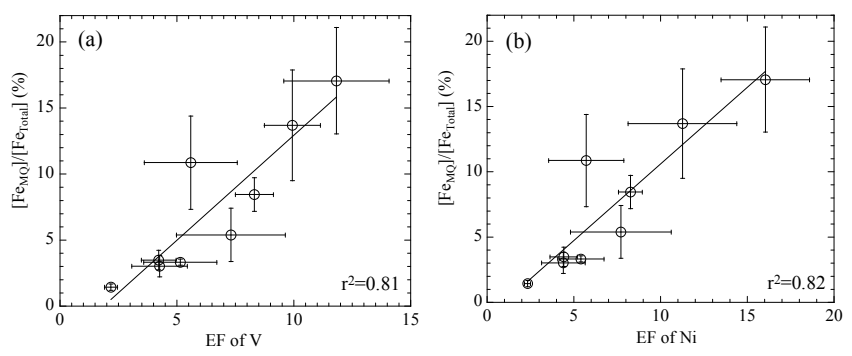

Fig. 12. Relationship of the EFs of (a) V and (b) Ni with the MQ water-soluble fraction of Fe. Error bars are standard deviations obtained by three independent experiments.

and $\mathrm{Ni}$ also originate from oil combustion (Sholkovitz et al., 2009). Sholkovitz et al. (2009) also showed that the soluble Fe fraction is correlated with the V/Al ratio and that $\mathrm{Fe}$ from fossil fuel combustion can leach into open ocean. Our results also support the hypothesis that $\mathrm{Fe}(\mathrm{III})$ sulfate originating from oil combustion, which can govern the dissolution of $\mathrm{Fe}$ into seawater, is the main component of soluble $\mathrm{Fe}$ in the aerosols.

There are other factors that can affect the amount of soluble Fe related to the sampling method employed in this study, such as (i) contribution of wet deposition and (ii) difference between troposphere below and above the atmospheric boundary layer (ABL). First, the amount of soluble $\mathrm{Fe}$ in the aerosols can be reduced by rain during the sampling period, which cannot be directly estimated in this study, since we did not collect wet deposition samples. In Table 1, (a) total precipitation, (b) number of rain events with total precipitation above $5 \mathrm{~mm}$, and (c) number of rainy days during the sampling period were given. In particular, the amount of time during which rain fell, or even the frequency of the rain is important rather than the total precipitation during the period, since one rain event can remove most of the water soluble components in the atmosphere whether it is heavy or light rain. For example, although the total precipitation is very high in August and October due to the heavy rain on 14-16 August and 13-14 October 2003, the numbers of rainy days were similar to those in the other months. Thus, it is not likely that the precipitation itself biases any particular month to compare the amount of soluble Fe in the dry deposition. However, we would like to point out here that the amount of soluble $\mathrm{Fe}$ in the atmosphere estimated in this study can be a minimum estimate, since $\mathrm{Fe}$ in wet deposition was not measured in our method. Second, the aerosol sample collected at the ground base below the ABL in this study can be different from that above ABL that is more important for the longrange transport to the open ocean (Uematsu et al., 2003). In addition, the solubility of $\mathrm{Fe}$ in the sample from free troposphere can be different from that in the lower troposphere. Thus, solubility and speciation of $\mathrm{Fe}$ in the aerosol in the free troposphere can be important to quantify the supply of soluble Fe to the open ocean. 


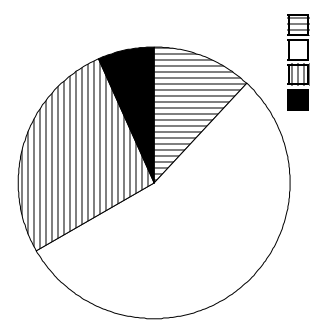

(a) $\left[\mathrm{Fe}_{\text {Total }}\right]$ for the year, by species

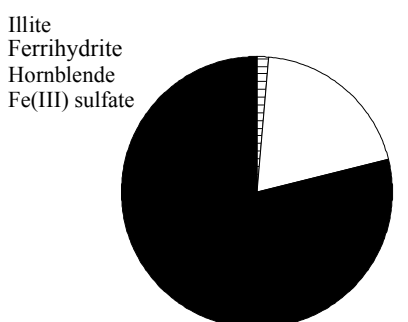

(b) $\left[\mathrm{Fe}_{\mathrm{sw}}\right]$ for the year, by species
Fig. 13. Contribution of each $\mathrm{Fe}$ species to (a) total $\left[\mathrm{Fe}_{\mathrm{Total}}\right]$ and (b) total $\left[\mathrm{Fe}_{\mathrm{SW}}\right]$ for all the months.

\subsection{Comparison of atmospheric concentrations of soluble Fe and soluble Fe fraction}

The period with large atmospheric concentrations of soluble $\mathrm{Fe}$ (either $\left[\mathrm{Fe}_{\mathrm{SW}}\right]$ or $\left[\mathrm{Fe}_{\mathrm{MQ}}\right]$ ) does not correspond exactly with that showing high soluble $\mathrm{Fe}$ fractions $\left(\left[\mathrm{Fe}_{\mathrm{Sw}}\right] /\left[\mathrm{Fe}_{\text {Total }}\right]\right.$ or $\left.\left[\mathrm{Fe}_{\mathrm{MQ}}\right] /\left[\mathrm{Fe}_{\mathrm{Total}}\right]\right)$ because the times at which total $\mathrm{Fe}$ was largest were not those when the soluble fraction was at maximum. In particular, total Fe was large during the dust storm season in East Asia, which does not contribute much to the pool of soluble $\mathrm{Fe}$. Thus, although the largest $\left[\mathrm{Fe}_{\text {Total }}\right]$ was observed in March, the soluble Fe concentration at Tsukuba was high in May, June, and July because Fe(III) sulfate was observed in these months. From a different viewpoint, the results showed that the soluble $\mathrm{Fe}$ fraction $\left(\left[\mathrm{Fe}_{\mathrm{SW}}\right] /\left[\mathrm{Fe}_{\mathrm{Total}}\right]\right.$ or $\left.\left[\mathrm{Fe}_{\mathrm{MQ}}\right] /\left[\mathrm{Fe}_{\text {Total }}\right]\right)$ increased with the decrease in the relative amount of mineral dusts due to the low solubility of $\mathrm{Fe}$ in the mineral dusts (Baker and Croot, 2010; Kumar and Sarin, 2010).

Journet et al. (2008) suggested that clay minerals in aerosols are a critical factor in the degree of Fe dissolution. Iron in clay minerals is definitely more soluble than Fe oxide (hematite or goethite) at low pH (Journet et al., 2008). However, $\mathrm{Fe}(\mathrm{III})$ sulfate is more soluble than Fe in clay minerals. Actually, clay minerals such as chlorite and illite cannot be a controlling factor of the amount of soluble Fe fraction in our aerosol samples, because the amount of clay minerals did not affect the $\left[\mathrm{Fe}_{\mathrm{SW}}\right] /\left[\mathrm{Fe}_{\text {Total }}\right]$ or $\left[\mathrm{Fe}_{\mathrm{MQ}}\right] /\left[\mathrm{Fe}_{\text {Total }}\right]$ ratios for each solution (Figs. 10 and 11).

These results are well illustrated in Fig. S9 and Fig. 13. Figures $\mathrm{S} 9 \mathrm{a}$ or $10 \mathrm{a}$ show that the contribution of $\mathrm{Fe}_{\text {Total }}$ in each month to the total amount of Fe for all the months is relatively larger in February, March, and May. However, similar values for $\mathrm{Fe}_{\mathrm{SW}}$ in these months to the total amount (Fig. S9b) were smaller than those found for $\mathrm{Fe}_{\text {Total }}$ Instead, the importance of June and July in terms of the supply of soluble $\mathrm{Fe}$, which can be strongly affected by the presence of $\mathrm{Fe}$ (III) sulfate in these two months, was clear in Fig. S9b (or Fig. 10a).

This situation is also distinctive in Fig. 13a and b. Figure 13a shows the contribution of each $\mathrm{Fe}$ species found in the aerosols samples to the total Fe for all the months, whereas Fig. 13b reflects the contribution of each Fe species to the total soluble Fe. Although ferrihydrite is the most abundant mineral in terms of the total Fe in Fig. 13a, the source of soluble $\mathrm{Fe}$ is mainly $\mathrm{Fe}(\mathrm{III})$ sulfate, as shown in Fig. 13b. This result, again, emphasizes the importance of $\mathrm{Fe}(\mathrm{III})$ sulfate as a source of soluble Fe in seawater.

\section{Conclusions and implications}

The soluble $\mathrm{Fe}$ concentrations in the ocean can be primarily related to the total $\mathrm{Fe}$ concentrations in the atmosphere $\left(\left[\mathrm{Fe}_{\text {Total }}\right]\right)$ and the soluble $\mathrm{Fe}$ fraction in the aerosol $\left(\left[\mathrm{Fe}_{\mathrm{Sol}}\right] /\left[\mathrm{Fe}_{\text {Total }}\right]\right)$. In this study, we revealed that the fraction of Fe(III) sulfate determined by XAFS was up to approximately $20 \%$ of the total $\mathrm{Fe}$ species in summer and that this fraction is correlated with the soluble Fe fraction determined in the leaching experiment. Thus, the amount of Fe(III) sulfate in aerosol can control the amount of soluble $\mathrm{Fe}$ in the sample. In terms of the concentration of soluble Fe in the ocean, $\mathrm{Fe}(\mathrm{III})$ sulfate can significantly influence marine primary production because of its high solubility.

In addition, the concentration of soluble $\mathrm{Fe}$ was found to be correlated with those of anthropogenic ions such as sulfate and oxalate and the EFs of $\mathrm{V}$ and $\mathrm{Ni}$, which are employed as the tracer elements of oil combustion. From these results, anthropogenic $\mathrm{Fe}$, especially $\mathrm{Fe}(\mathrm{III})$ sulfate emitted during oil combustion, is a critical factor in estimating the amount of soluble $\mathrm{Fe}$ in aerosols. Generally speaking, anthropogenic aerosol is rich in fine particles, thus, anthropogenic Fe(III) sulfate can be transported over relatively long distances and can have a great impact on phytoplankton activity in the open ocean. Iron in mineral dusts, especially in the dust storm season, is possibly an important Fe source in the North Pacific, but the contribution of $\mathrm{Fe}$ (III) sulfate from megacities in eastern Asia must not be disregarded.

\section{Supplementary material related to this article is available online at: http://www.atmos-chem-phys.net/13/ 7695/2013/acp-13-7695-2013-supplement.pdf.}

Acknowledgements. We are grateful to H. Kamioka, S. Yabuki, and A. Ohta for collecting the aerosol samples for the ADEC project. This research was supported by a Grant-in-Aid for Scientific Research in Priority Areas, "Western Pacific Air-Sea Interaction Study (W-PASS)." This work was performed with the approval of KEK-PF (2011G197, 2011G644, and 2012G111) and SPring-8 (2012A1240 and 2002B1428). This research is a contribution to the Surface Ocean Lower Atmosphere Study (SOLAS). The operations of the Advanced Light Source at the Lawrence Berkeley National Laboratory are supported by the Director of the Office of Science, Office of Basic Energy Sciences, US Department of Energy under contract number DE-AC02-05CH11231. This study was also partially supported by Chinese Academy of Sciences 
Visiting Professorship for Senior International Scientists (Grant No. 2012T1Z0035) and National Natural Science Foundation of China (No. 41273112).

Edited by: A. B. Guenther

\section{References}

Aguilar-Islas, A. M., Wu, J., Rember, R., Johansen, A. M., and Shank, L. M.: Dissolution of aerosol-derived iron in seawater: leach solution chemistry, aerosol type, and colloidal iron fraction, Mar. Chem., 120, 25-33, 2010.

Baker, A. R. and Croot, P. L.: Atmospheric and marine controls on aerosol iron solubility in seawater, Mar. Chem., 120, 4-13, 2010.

Baker, A. R. and Jickells, T. D.: Mineral particle size as a control on aerosol iron solubility, Geophys. Res. Lett., 33, L17608, doi:10.1029/2006GL026557, 2006.

Beauchemin, S., Hesterberg, D., and Beauchemin, M.: Principal component analysis approach for modeling sulfur K-XANES spectra of humic acids, Soil Sci. Soc. Am. J., 66, 83-91, 2002.

Bishop, J. K. B., Davis, R. E., and Sherman, J. T.: Robotic observations of dust storm enhancement of carbon biomass in the North Pacific, Science, 298, 817-821, 2002.

Boyd, P. W. and Ellwood, M. J.: The biogeochemical cycle of iron in the ocean, Nat. Geosci., 3, 675-682, 2010.

Boyd, P., Jickells, T. D., Law, C. S., Blain, S., Boyle, E. A., Buesseler, K. O., Coale, K. H., Cullen, J. J., de Baar, H. J. W., Follows, M., Harvey, M., Lancelot, C., Levasseu, M., Owens, N., P. J., Pollard, R., Rivkin, R. B., Sarmiento, J., Schoemann, V., Smetacek, V., Takeda, S., Tsuda, A., Turner, S., and Watson, A. J.: Mesoscale iron enrichment experiments 1993-2005: synthesis and future directions, Science, 315, 612-617, 2007.

Bruland, K. W. and Lohan, M. C.: Controls of Trace Metals in Seawater, The Oceans and Marine Geochemistry, 6, Treatise on Geochemistry, Elsevier Ltd, 2003.

Buck, C. S., Landing, W. M., and Resing, J. A.: Particle size and aerosol iron solubility: a high resolution analysis of Atlantic aerosols, Mar. Chem., 120, 14-24, doi:10.1016/j.marchem.2008.11.002, 2010.

Chen, Y. Z., Shah, N., Huggins, F. E., and Huffman, G.: Investigation of the microcharacteristics of PM2.5 in residual oil fly ash by analytical transmission electron microscopy, Environ. Sci. Technol., 38, 6553-6560, 2004.

Claquin, T., Schulz, M., and Balkanski, Y.: Modeling the mineralogy of atmospheric dust sources, J. Geophys. Res., 104, 2224322256, 1999.

David, R. L.: Handbook of Chemistry and Physics, 75th Edn., CRC Press, Inc., USA, 1994.

Desboeufs, K. V., Losno, R., Vimeux, F., and Cholbi, S.: The pH dependent dissolution of wind-transported Saharan dust, J. Geophys. Res., 104, 21287-21299, 1999.

Draxler, R. R. and Rolph, G. D.: HYSPLIT (HYbrid Single-Particle Lagrangian Integrated Trajectory) Model access via NOAA ARL READY Website, available at: http://ready.arl.noaa.gov/ HYSPLIT.php, NOAA Air Resources Laboratory, Silver Spring, MD, USA, 2003.

Duce, R. A., Unni, C. K. Ray, B. J., Prospero, J. M., and Merrill, J. T.: Long-range atmospheric transport of soil dust from Asia to the tropical North Pacific: Temporal variability, Science, 209, 1522-1524, 1980.

Duce, R. A., Liss, P. S., Merrill, J. T., Atlas, E. L., Buat-Menard, P., Hicks, B. B., Miller, J. M., Prospero, J. M., Arimoto, R., Church, T. M., Ellis, W., Galloway, J. N., Hansen, L., Jickells, T. D., Knap, A. H., Reinhardt, K. H., Schneider, B., Soudine, A., Tokos, J. J., Tsunogai, S., Wollast, R., and Zhou, M.: The atmospheric input of trace species to the world ocean, Global Biogeochem. Cy., 5, 193-259, 1991.

Furukawa, T. and Takahashi, Y.: Oxalate metal complexes in aerosol particles: implications for the hygroscopicity of oxalatecontaining particles, Atmos. Chem. Phys., 11, 4289-4301, doi:10.5194/acp-11-4289-2011, 2011.

Hasegawa, H., Maki, T., Asano, K., Ueda, K., and Ueda, K.: Detection of iron(III)-binding ligands originating from marine phytoplankton using cathodic stripping voltammetry, Anal. Sci., 20, 89-93, 2004.

Ito, A.: Global modeling study of potentially bioavailable iron input from shipboard aerosol sources to the ocean, Globa. Biogeochem. Cy., 27, 1-10, doi:10.1029/2012GB004378, 2013.

Jambor, J. L. and Dutrizac, J. E.: Occurrence and constitution of natural and synthetic ferrihydrite, a widespread iron oxyhydroxide, Chem. Rev., 98, 2549-2585, 1998.

Jang, H. N., Seo, Y. C., Lee, J. H., Hwang, K. W., Yoo, J. I., Sok, C. H., and Kim, S. H.: Formation of fine particles enriched by V and $\mathrm{Ni}$ from heavy oil combustion: Anthropogenic sources and drop-tube furnace experiments, Atmos. Environ., 41, 1053-1063, 2007.

Jickells, T. D. and Spokes, L. J.: Atmospheric Iron Inputs to the Oceans, in: The Biogeochemistry of Iron in Seawater, edited by: Turner, D. R. and Hunter, K., SCOR/IUPAC Series, Wiley, 85121, 2001.

Jickells, T. D., An, Z. S., Andersen, K. K., Baker, A. R., Bergametti, G., Brooks, N., Cao, J. J., Boyd, P. W., Duce, R. A., Hunter, K. A., Kawahata, H., Kubilay, N., LaRoche, J., Liss, P. S., Mahowald, N., Prospero, J. M., Ridgwell, A. J., Tegen, I., and Torres, R.: Global iron connections between desert dust, ocean biogeochemistry, and climate, Science, 308, 67-71, 2005.

Journet, E., Desboeufs, K. V., Caquineau, S., and Colin, J. L.: Mineralogy as a critical factor of dust iron solubility, Geophys. Res. Lett., 35, L07805, doi:10.1029/2007GL031589, 2008.

Kanai, Y., Ohta, A., Kamioka, H., Terashima, S., Imai, N., Matsuhisa, Y., Kanai, M., Shimizu, H., Takahashi, Y., Kai, K., Xu, B., Hayashi, M., and Zhang, R.: Variation of concentrations and physicochemical properties of aeolian dust obtained in east China and Japan from 2001 to 2002, Bull. Geol. Surv. Jpn., 54, 251-267, 2003.

Kumar, A. and Sarin, M. M.: Aerosol iron solubility in a semiarid region: temporal trend and impact of anthropogenic sources, Tellus, 62B, 125-132, 2010.

Kraemer, S. M.: Iron oxide dissolution and solubility in the presence of siderophores, Aquat. Sci., 66, 3-18, 2004.

Kupiainen, K., Tervahattu, H., and Räisänen, M.: Experimental studies about the impact of traction sand on urban road dust composition, Sci. Total Environ., 308, 175-184, 2003.

Kupiainen, K., Tervahattu, H., Räisänen, M., Mäkelä, T., Aurela, M., and Hillamo, R.: Size and Composition of Airborne Particles from Pavement Wear, Tires, and Traction Sanding, Environ. Sci. Technol., 39, 699-706, 2005. 
Lam, P. J. and Bishop, J. K. B.: The continental margin is a key source of iron to the HNLC North Pacific Ocean, Geophys. Res. Lett., 35, L07608, doi:10.1029/2008GL033294, 2008.

Langmann, B., Zakšek, K., Hort, M., and Duggen, S.: Volcanic ash as fertiliser for the surface ocean, Atmos. Chem. Phys., 10, 38913899, doi:10.5194/acp-10-3891-2010, 2010.

Léon, A., Kircher, O., Rothe, J., and Fichtner, M.: Chemical state and local structure around titanium atoms in $\mathrm{NaAlH}_{4}$ doped with $\mathrm{TiCl}_{3}$ using X-ray absorption spectroscopy, J. Phys. Chem. B, 108, 16372-16376, 2004.

Luo, C., Mahowald, N., Bond, T., Chuang, P. Y., Artaxo, P., Siefert, R., Chen, Y., and Schauer, J.: Combustion iron distribution and deposition, Global Biogeochem. Cy., 22, GB1012, doi:10.1029/2007GB002964, 2008.

Mackie, D. S., Boyd, P. W., Hunter, K. A., and McTainsh, G. H.: Simulating the cloud processing of iron in Australian dust: $\mathrm{pH}$ and dust concentration, Geophys. Res. Lett., 32, L06809, doi:10.1029/2004GL022122, 2005.

Mahowald, N. M., Baker, A. R., Bergametti. G., Brooks, N., Duce, R. A., Jickells, T. D., Kubilay, N., Prospero, J. M., and Tegen, I.: Atmospheric global dust cycle and iron inputs to the ocean, Global Biogeochem. Cy., 19, GB4025, doi:10.1029/2004GB002402, 2005.

Majestic, B. J., Schauer, J. J., and Shafer, M. M.: Application of synchrotron radiation for measurement of iron red-ox speciation in atmospherically processed aerosols, Atmos. Chem. Phys., 7, 2475-2487, doi:10.5194/acp-7-2475-2007, 2007.

Manceau, A., Marcus, M. A., and Tamura, N.: Quantitative speciation of heavy metals in soils and sediments by synchrotron X-ray techniques, in: Applications of Synchrotron Radiation in LowTemperature Geochemistry and Environmental Science, edited by: Fenter, P. and Sturchio, N. C., Reviews in Mineralogy and Geochemistry, Mineralogical Society of America, Washington, DC., 49, 341-428, 2002.

Manoli, E., Voutsa, D., and Samara, C.: Chemical characterization and source identification/ apportionment of fine and coarse air particles in Thessaloniki, Greece, Atmos. Environ., 36, 949-961, 2002.

Marcus, M., MacDowell, A. A., Celestre, R., Manceau, A., Miller, T., Padmore, H. A., and Sublett, R. E.: Beamline 10.3.2 at ALS: a hard X-ray microprobe for environmental and materials sciences, J. Synchrotron Rad., 11, 239-247, 2004.

Marcus, M. A., Westphal, A. J., and Fakra, S. C.: Classification of Fe-bearing species from K-edge XANES data using twoparameter correlation plots, J. Synchrotron Rad., 15, 463-468, 2008.

Martell, A. E. and Smith, R. M.: Critical Stability Constants, Plenum Press, New York, 1982.

Martin, J. H.: Glacial-interglacial $\mathrm{CO}_{2}$ change: the iron hypothesism Paleoceanograpy, 5, 1-13, 1990.

Martin, J. H. and Fitzwater, S. E.: Iron deficiency limits phytoplankton growth in the north-east Pacific subarctic, Nature, 331, 341343, 1988.

Martinez, E. and Maamaatuaiahutapu, K.: Island mass effect in the Marquesas Islands: Time variation, Geophys. Res. Lett., 31, L18307, doi:10.1029/2004GL020682, 2004.

Oakes, M., Weber, R. J., Lai, B., Russell, A., and Ingall, E. D.: Characterization of iron speciation in urban and rural single particles using XANES spectroscopy and micro X-ray fluorescence measurements: investigating the relationship between speciation and fractional iron solubility, Atmos. Chem. Phys., 12, 745-756, doi:10.5194/acp-12-745-2012, 2012a.

Oakes, M., Ingall, E. D., Lai, B., Shafer, M. M., Hays, M. D., Liu, Z. G., Russell, A. G., and Weber, R. J.: Iron solubility related to particle sulfur content in source emission and ambient fine particles, Environ. Sci. Technol., 46, 6637-6644, 2012b.

Ooki, A., Nishioka, J., Ono, T., and Noriki, S.: Size dependence of iron solubility of Asian mineral dust particles, J. Geophys. Res., 114, D03202, doi:10.1029/2008JD010804, 2009.

Paris, R., Desboeufs, K. V., Formenti, P., Nava, S., and Chou, C.: Chemical characterisation of iron in dust and biomass burning aerosols during AMMA-SOP0/DABEX: implication for iron solubility, Atmos. Chem. Phys., 10, 4273-4282, doi:10.5194/acp10-4273-2010, 2010.

Paris, R., Desboeufs, K. V., and Journet E.: Variability of dust iron solubility in atmospheric waters: Investigation of the role of oxalate organic complexation, Atmos. Environ., 45, 6510-6517, 2011.

Schroth, A. W., Crusius, J., Sholkovitz, E. R., and Bostick, B. C.: Iron solubility driven by speciation in dust sources to the ocean, Nat. Geosci., 2, 337-340, 2009.

Sedwick, P. N., Sholkovitz, E. R., and Church, T. M.: Impact of anthropogenic combustion emissions on the fractional solubility of aerosol iron: Evidence from the Sargasso Sea, Geochem. Geophys. Geosyst., 8, Q10Q06, doi:10.1029/2007GC001586, 2007.

Seinfeld, J. H. and Pandis, S. N.: Atmospheric Chemistry and Physics: From Air Pollution to Climate Change, 2nd Edn., John Wiley and Sons, NY, USA, 2006.

Seiter, J. M., Staats-Borad, K. E., Ginder-Vogel, M., and Sparks, D. L.: XANES spectroscopic analysis of phosphorus speciation in alum-amended poultry litter, J. Environ. Qual., 37, 477-485, 2008.

Shi, Z., Krom, M. D., and Bonneville, S.: Formation of iron nanoparticles and increase in iron reactivity in mineral dust during simulated cloud processing, Environ. Sci. Technol., 43, 6592-6596, 2009.

Sholkovitz, E. R., Sedwick, P. N., and Church, T. M.: Influence of anthropogenic combustion emissions on the deposition of soluble aerosol iron to the ocean: Empirical estimates for island sites in the North Atlantic, Geochim. Cosmochim. Acta, 73, 3981-4003, 2009.

Shukla, A. K., Raman, R. K., Choudhury, N. A., Priolkar, K. R., Sarode, P. R., Emura, S., Kumashiro, R.: Carbon-supported Pt-Fe alloy as a methanol-resistant oxygen-reduction catalyst for direct methanol fuel cells, J. Electroanal. Chem., 563, 181-190, 2004.

Spokes, L. J. and Jickells, T. D.: Factors controlling the solubility of aerosol trace metals in the atmosphere and on mixing into seawater, Aqua. Geochem., 1, 355-374, 1996.

Takahashi, Y., Minai, Y., Ambe, S., Makide, Y., Ambe, F., and Tominaga, T.: Simultaneous determination of stability constants of humate complexes with various metal ions using multitracer technique, Sci. Total Environ., 198, 61-71, 1997.

Takahashi, Y., Higashi, M., Furukawa, T., and Mitsunobu, S.: Change of iron species and iron solubility in Asian dust during the long-range transport from western China to Japan, Atmos. Chem. Phys., 11, 11237-11252, doi:10.5194/acp-1111237-2011, 2011. 
Taylor, S. R.: Abundance of chemical elements in the continental crust: a new table, Geochem. Cosmochim. Acta, 28, 1273-1285, 1964.

Uematsu, M., Wang, Z. F., and Uno, I.: Atmospheric input of mineral dust to the western North Pacific region based on direct measurements and a regional chemical transport model, Geophys. Res. Lett., 30, 1342, doi:10.1029/2002GL016645, 2003.

Uematsu, M., Hattori, H., Nakamura, T., Narita, Y., Jung, J., Matsumoto, K., Nakaguchi, Y., and Kumar, M. D.: Atmospheric transport and deposition of anthropogenic substances from the Asia to the East China Sea, Mar. Chem., 120, 108-115, 2010.

Var, F., Narita, Y., and Tanaka, S.: The concentration trend and seasonal variation of metals in the atmosphere in 16 Japanese cities shown by the results of National Air Surveillance Network (NASN) from 1974 to 1996, Atmos. Environ., 34, 2755-2770, 2000 .
Wilke, M., Farges, F., Petit, P., Brown Jr., G. E., and Martin, F.: Oxidation state and coordination of fe in minerals: An Fe K-XANES spectroscopic study, Am. Mineral., 86, 714-730, 2001.

Witter, A. E., Hutchins, D. A., Butler, A., and Luther, G. W.: Determination of conditional stability constants and kinetic constants for strong model Fe-binding ligands in seawater, Mar. Chem., 69, $1-17,2000$.

Xie, R. K., Seip, H. M., Leinum, J. R., Winje, T., and Xiao, J. S.: Chemical characterization of individual particles (PM10) from ambient air in Guiyang City, China, Sci. Total Environ., 343, 262-272, 2005. 